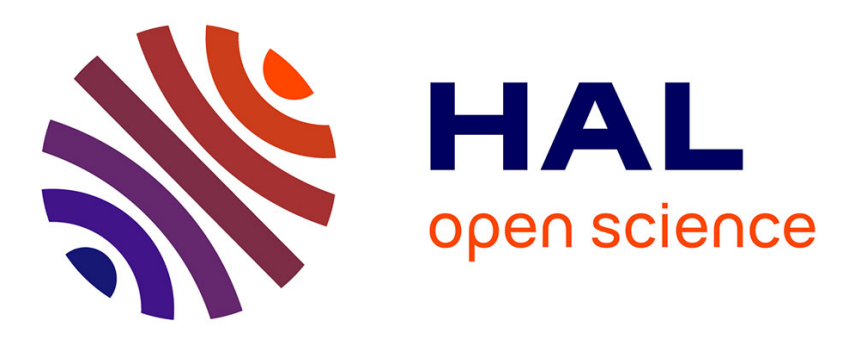

\title{
Commodity variety and seaport performance
}

\author{
César Ducruet, Hans R.A. Koster, Daniel J. van Der Beek
}

\section{To cite this version:}

César Ducruet, Hans R.A. Koster, Daniel J. van Der Beek. Commodity variety and seaport performance. Regional Studies, 2010, 44 (9), pp.1221-1240. 10.1080/00343400903167904. halshs00458596

\section{HAL Id: halshs-00458596 \\ https://shs.hal.science/halshs-00458596}

Submitted on 21 Feb 2010

HAL is a multi-disciplinary open access archive for the deposit and dissemination of scientific research documents, whether they are published or not. The documents may come from teaching and research institutions in France or abroad, or from public or private research centers.
L'archive ouverte pluridisciplinaire HAL, est destinée au dépôt et à la diffusion de documents scientifiques de niveau recherche, publiés ou non, émanant des établissements d'enseignement et de recherche français ou étrangers, des laboratoires publics ou privés. 


\section{Commodity variety and seaport performance}

Published in Regional Studies (DOI: 10.1080/00343400903167904)

César DUCRUET ${ }^{1}$

Centre National de la Recherche Scientifique (CNRS)

Université de Paris I Sorbonne

UMR 8504 Géographie-cités

Equipe P.A.R.I.S.

13 rue du Four

F-75006 Paris

France

Tel. +33 (0)140-464-007

Fax +33(0)140-464-009

Email: ducruet@parisgeo.cnrs.fr

Hans R.A. KOSTER

Erasmus University

School of Economics

Faculty of Applied Economics

Burg. Oudlaan 50

Woudestein Campus

P.O. Box 1738

3000 DR Rotterdam

The Netherlands

Email: hkoster@few.eur.nl

Daniel J. VAN DER BEEK

Erasmus University

School of Economics

Faculty of Applied Economics

Burg. Oudlaan 50

Woudestein Campus

P.O. Box 1738

3000 DR Rotterdam

The Netherlands

Email: 300395db@student.eur.nl 


\title{
Commodity variety and seaport performance
}

\author{
Abstract \\ Seaports are key locations within value chains and production networks. Port policies of \\ national and local governments seek higher rents through strategies of specialisation or \\ diversification. Elaborating on longstanding research about urban and regional development, \\ this paper proposes an empirical investigation of the interplay between traffic variety and port \\ performance. The analysis of traffic data per commodity for 330 European ports highlights \\ the influence of multiple factors such as location, function, and local context, together with \\ the specificity of some commodities regarding port evolution. The demonstrated importance \\ of territorial factors provides a good complement to existing literature mostly focused on \\ global networks and economic players. \\ Keywords: Commodity, Diversity, Europe, Port, Specialization, Traffic
}

\section{Introduction}

The changing locations of economic activities are increasingly influenced by external phenomena such as changes in the spatial organisation of commodity chains (GEREFFI and KORZENIEWICZ, 1994) and production networks (DICKEN et al., 2001) in which they are embedded. However, as LESLIE and REIMER (1999) argue, the literature on the global commodity chain has largely ignored the material realities of production as well as the particularity of individual nodes such as seaports. Recent research on ports provides conceptual insights about the benefits of a durable insertion in global value and supply chains (WANG et al., 2007; JACOBS and HALL, 2007), but systematic empirical verification is lacking (JACOBS et al., 2009). It remains very unclear whether the enormous investment cost of new port facilities at either greenfield sites or existing port areas is justified by sufficient 
externalities brought by the concentration of commodity and logistics chains. While urban and regional studies have long emphasised how cities develop through functional diversification (PAULUS, 2004; PUMAIN and FAVARO, 2008), there is little evidence that ports should diversify their activity in order to become more competitive.

From transport geographers' point of view, the raison-d'être of seaports is the generation of cargo throughputs and provision of economies of scale for industries by means of connecting various locations through land and sea transport networks (WEIGEND, 1958; VIGARIÉ, 1979). Two major types of changes affect contemporary seaports: technological and economical. First, the global shift from break-bulk cargo to containers has forced a sharp reduction of ports capable of adapting to the new technology. Many terminals and piers have became obsolete (MAYER, 1973), resulting in a tendency towards tonnage and berth specialisation (VON SCHIRACH-SZMIGIEL, 1973). Second, the level of port activities increasingly depends on the strategies of external players on the level of the entire supply and value chain such as shippers, freight forwarders, intermodal operators, and shipping lines (SLACK, 1985; ROBINSON, 2002; DUCRUET and VAN DER HORST, 2009). These two trends combine locally, resulting in lack of space for further expansion and the search for improvements in cargo handling technologies and hinterland accessibility. Ports grow or decline within port systems depending on their ability answering such challenges (LEE et al., 2008).

While extensive research on port performance lists numerous factors, limited attention has been paid to the composition of traffic. This angle of attack is inspired from two important sets of theories. Economists developed the dependency theory in the 1950s, considering commodity specialisation as a weakness for countries regarding price fluctuations and economic growth. However, such theory is controversial and lacks empirical evidence (LUDEMA, 2001). On the other hand, urban geographers developed the central place theory, 
which relates the functional diversity of cities with urban size (CHRISTALLER, 1933; CLARK, 1945). Although this theory is questioned by a number of scholars, there is a consensus that large cities dominate the urban hierarchy because they offer a diversified environment fostering economic growth and social relations (QUIGLEY, 1998; TAYLOR et al. 2002; FLORIDA, 2004; OTTAVIANO and PERI, 2006). In particular, the cosmopolitanism of maritime cities has long been a key element of their growth (CARTIER, 1999; LAWTON and LEE, 2002).

Whether this framework applies to ports has never been tested systematically, although specialisation and diversification are two fundamental dimensions of contemporary port development on various scales (Table 1). These interlocked factors become materialised locally through the action of firms, governments, and port authorities. Port traffic can be defined as a multi-scalar measure that condenses the level and quality of port insertion within commodity and value chains. While this issue is of chief concern to port specialists, it also corresponds to a wider concern about the economic advantages or disadvantages of spatial concentration in a global environment (FUJITA et al., 1999; KAPLINSKY, 2004). This seems important for three main reasons:

[Insert Table 1 about here]

- Conceptual: the notion of specialisation in port studies is rather vague and may refer to trade routes (e.g. Hamburg and Chinese trade), geographical coverage (e.g. global, regional, local ports), functions (e.g. hub ports, gateway ports, transit ports), and governance (e.g. landlord port, private port, municipal port). This paper refers to the definition proposed by BRUNET (1993) for whom specialisation is the domination of one or more activities at a given place. Specialisation can also be defined as the relative weight of some activities 
proportionally to other places on average. For ports, commodity variety corresponds to the distribution of traffic types (e.g. general cargo, bulk, containers, and ro-ro ${ }^{2}$ ), which result in an equivalent variety of land-use and cargo handling facilities.

- Methodological: scarce data on detailed port traffic explains the lack of international comparative studies. Ports are often compared based on aggregated figures of total yearly throughputs. Existing research on the distribution and value added of port traffic does not relate with performance in terms of traffic volume or growth (CHARLIER, 1994; HAEZENDONCK et al., 1999; ROZENBLAT, 2004). Are bigger ports always more diversified? Are specialised ports always smaller ports? Does commodity variety constitute a comparative advantage for seaports? While such questions may appear rather trivial to port specialists, the lack of empirical evidence prevents the formulation of any serious answer.

- $\quad$ Practical: the marketing strategy of several port authorities ${ }^{3}$ introduces commodity variety as a key asset in port competition and performance. Traffic diversification is a widely spread - albeit costly - strategy (i.e. investment in new facilities), while the pursuit of specialisation refers to the reinforcement of existing facilities (e.g. terminal expansion). Surprisingly, few scholars have examined the impact of commodity-based strategies on the evolution of port systems. One exception is HALL (2004) who looks at how automobile imports at US ports stimulate a process of mutual specialisation between firm strategies and port policies. Earlier works identified local factors constraining or facilitating the diffusion of containerisation to non-container ports in Indonesia and China (AIRRIESS, 1989; 2001). Such analyses demonstrate the complementarity between hinterland characteristics and the action of public and private players involved in port development.

[Insert Table 1 about here] 
This paper confronts these issues head on by analysing a European-wide database on commodity-based traffic for 330 seaports. The remainders of the paper are organised as follows. In section 2, the theoretical framework is proposed based on the urban literature on city size and economic specialisation. Section 3 addresses methodological issues of data preparation and sample selection. Section 4 presents the main results of the analysis of commodity specialisation and diversity. Finally, section 5 presents the implications of the findings for the port industry and further research.

\section{Specialisation of cities and application to seaports}

The functional specialisation of cities is one major approach to the study of urban development and urban systems. Cities exert administrative, political, economical, cultural, transport, and communication functions, which tend to concentrate across space while giving birth to an urban hierarchy (PUMAIN, 1982). Specialisation varies through different levels of aggregation, in terms of sectors (e.g. industry, services), activities (e.g. mining, thermal, retail,

tourism), and products (e.g. textile, steelworks) ${ }^{4}$. The recent conceptual and methodological synthesis provided by DURANTON and PUGA (2000) is chosen as a base for further application to the case of ports. Four main stylised facts are retained among five for their application to seaports, and their framework is complemented by a review of other scholarly works.

\subsection{Specialised and diversified locations}

In nearly every country, diversified cities coexist with specialised cities. While cities may specialise due to random or natural factors (e.g. composition of resources in a given region), it has become increasingly related to interactions among firms of the same industry or 
localisation economies (MARSHALL, 1890; HENDERSON, 1997a). On the other hand, diversified cities emerge through interactions between firms of different sectors or urbanisation economies (JACOBS, 1969). MARSHALL (1890) identifies three factors influencing localisation economies. First, local non-traded specialised inputs are produced more efficiently than in the case of a uniform distribution across the country. Second, firms with similar knowledge bases create information spillovers through the exchange of tacit information among employees from specialised firms. Such information is incomplete and shared on a non-market basis. A third factor is the existence of a specialised labour pool that lowers labour acquisition costs (e.g. training) for firms seeking skilled workers. When it comes to ports, localisation economies are commodity-specific creating traffic specialisation, while urbanisation economies are port-specific enabling traffic diversity. Two main factors seem to influence traffic variety:

- Continental hinterland: according to HAEFNER et al. (1980) and MARTI (1985), commodity specialisation of individual port sites occurs in relation with geographic affinity for specific cargo types of the outlying region. Ports with a large and diverse hinterland may handle a greater variety of cargoes than ports with a narrow and specialised hinterland (e.g. mine or forest products). However, several ports may serve the same hinterland, resulting in a spatial distribution of commodities, as seen in the case of former USSR ports centred on Moscow (THOREZ, 1998), or in the case of a contestable hinterland such as Austria (DE LANGEN, 2007). Ports may also struggle for the same commodity over a shared hinterland, as seen in the case of ore imports (TODD, 2003). Quality of hinterland access through efficient connection with complementary transport modes (e.g. rail, river) has become a key determinant of port competition nowadays (VAN DER HORST and DE LANGEN, 2008). 
- Local economy: ports may develop into specific industrial clusters (e.g. oil, refinery, and petrochemicals) using economies of scale and creating synergy effects among selected activities (DE LANGEN, 2003). The variety of the urban economy surrounding the port largely explains traffic diversity in the US (CARTER, 1962). Even in constrained economies such as North Korea, the size and diversity of coastal economies is reflected in the volume and nature of seaports' traffic (DUCRUET and JO, 2008). While many large agglomerations of the world are also important maritime gateways, diseconomies of scale due to lack of space and congestion in the urban core have provoked a spatial and functional separation between port and urban activities shifting specialised terminals to the urban fringe (BIRD, 1963; HOYLE, 1989).

\subsection{The relation between size and variety}

DURANTON and PUGA (2000) indicate a noticeable correlation between the size of cities and their degree of functional diversity: larger cities develop wider economic portfolios. However, the level of this correlation is not very high because a number of local economic activities are non-tradable. Accordingly, HENDERSON (1988) underlined that cities specialising in similar activities have a similar size, but his work is based on a small sample of cities within the manufacturing sector only, and the standard deviations are often quite high. In their study on regional specialisation and transport costs, TABUSHI and THISSE (2002) underline that spatial agglomeration forces are commodity-specific and therefore depend on a certain degree of regional specialisation. For instance, heavy industries and industries producing goods with high transport costs are more agglomerated than light industries and industries with lower transport costs.

In terms of ports, we expect larger ports to be more diversified, due to the effect of their role as gates for large continental hinterlands or coastal agglomerations. However, not 
every port can handle every cargo, due to site physical constraints (e.g. deepwater ports welcome larger vessels), and specific cargo handling requirements (e.g. ramps for ro-ro ports, and gantry cranes for containerships). Some large port gateways may circumvent such limitations to a great extent, such as in New York where massive dredging programme permitted it to accommodate super-post-panamax container vessels. CARTER (1962, p. 171) states that "the variety of commerce has also great significance for a port economy," because multiple handling facilities attract diversified skills, and create more value. In his study of US ports, CARTER (1962) also remarks that all international ports are diversified in their traffic composition, while most small ports handle a limited variety of cargoes since $80 \%$ of them have more than $50 \%$ their traffic concentrated in one single commodity. This is confirmed by KUBY and REID (1992) in their comparison of the US smallest ports, whose imports depend on one or two dominant products used as intermediate inputs by local industries, such as lumber, steel, chemicals, and fibres. Moreover, the concentration of liner cargo and containers at larger ports harms the development of smaller ports. The works of KENYON (1970) and FORWARD (1984) clearly show how New York and Vancouver dominate neighbouring ports due to their status of diversified metropolis. Thus, the diversification strategy of small and medium-sized ports is a response to limited hinterland accessibility and the risk of depending too much on financially fluctuating commodities (DE LANGEN, 1998; TODD, 2000). Of great importance is also the functional autonomy of the port city with regard to the lock-in effect exerted by inland core regions on coastal gateways (STERN and HAYUTH, 1984; FUJITA and MORI, 1996). As empirically tested by DUCRUET and VAN DER HORST (2009) in Europe, Northern range ports are more diversified than Southern ports in terms of respective intra-firm transport integration because they serve bigger and more spatially concentrated markets. 


\subsection{The evolution of variety and size}

With respect to cities, despite some exceptions, the relative city size in the US has changed very little: there is a pattern of overall stability in the US urban system. There is not only stability in the system but also within cities. Both the composition of economic activities and specialisation patterns are stable over time (HENDERSON, 1999).

The stability of port hierarchies has been observed in several regions of the world where either concentration or de-concentration occur (DUCRUET et al., 2009). Nevertheless, changes in the composition of traffic may not be reflected in total traffic figures. Another dimension of traffic evolution is the relation with the economic structure of the regional environment. For instance, SHARPLESS (1976) demonstrates that for two port cities of equivalent size and industries, traffic evolution differs due to contrasted urban competition regionally and nationally. Over the last three decades, container traffic has increasingly concentrated at larger cities globally, although the correlation between urban size and container traffic has dramatically dropped, due to local constraints, regional competition, and global strategies (DUCRUET and LEE, 2006). The neoclassical model of FUJITA and MORI (1996) suggests that port-related urban growth is more likely to happen in remotely located regions where specialised industries develop specific local resources into comparative advantages. In developed countries on average, traffic growth is lower in industrial regions than in tertiary regions due to globalisation (DUCRUET, 2009). Local strategies may radically modify traffic evolution. However, the black box of containerisation avoids a detailed knowledge of the content of shipments. ${ }^{5}$ Notably, containers absorb an increasing share of general cargo, bulk and neo-bulk products, which makes container ports diversified by nature.

2.4 The relation between growth and variety 
MARSHALL (1890), ARROW (1962), and ROMER (1986) hypothesise that specialisation spurs regional economic growth, while JACOBS (1969) states that diversity promotes regional growth. Such debate is complemented by several empirical studies that were recently synthesised by BUN and EL MAKHLOUFI (2007) and appear in Table 2. Most studies use employment growth on a regional level (e.g. province) as a proxy for regional economic performance: the more jobs that are created, the stronger the economic growth. In general, economic growth depends on which sector a city or region adopts (HENDERSON et al., 1995). Specialisation in manufacturing activities is more likely to be a weakness in an age of globalisation than specialisation in high-tech industries and advanced producer services that are less footloose. Specialisation and diversification are in fact interdependent because they follow successive development paths.

[Insert Table 2 about here]

Throughout port studies, there is not much evidence for a direct relationship between commodity variety and traffic growth. Given the complexity of contemporary transport chains and port selection mechanisms, it has become doubtful whether new investments in port infrastructure will inevitably result in traffic growth due to overcapacity (GOSS, 1990). Interesting evidence is offered by LEMARCHAND and JOLY (2009) about the relationship between traffic size and traffic growth rate among port ranges worldwide. Port traffic deviates from Gibrat's law: volume and growth are inversely proportionate on average, because bigger ports have reached a stage of maturity protecting them against external shocks, such as financial cycles and economic fluctuations (HANAPPE and SAVY, 1981). Conversely, smaller ports depend on a few customers for a majority of their traffic. 
Although our review of the existing literature cannot be fully exhaustive due to the amount of related works on the subject, it allows for expressing four main hypotheses basing the application of urban and regional theories to seaports:

- H1: diversified ports coexist with specialised ports: within various geographical levels (e.g. region, country, continent), some ports handle a greater variety of cargoes than other ports, which traffic tend to be dominated by fewer commodities;

- $\quad$ H2: larger ports tend to be more diversified: ports which, for some reason, generate more cargo than other ports, also handle a greater variety of cargoes compared with smaller ports;

- H3: the patterns of traffic volume and commodity variety portfolio are stable over time: within a given period of time, the port hierarchy and the composition of traffic are not likely to change rapidly, but traffic growth should go through successive stages of specialisation and diversification;

- H4: port performance and commodity variety are related to each other: either by unilateral impact or circular causation, competitive ports are those which deploy a variety of commodities as a key asset in performance.

\section{Data source, sample selection, and methodology}

\subsection{Data set}

The data used in this paper is drawn from Eurostat, ${ }^{6}$ which provides traffic figures per 30 commodities in metric tons for virtually every port in Europe between 1997 and 2006. Although data is available by quarters, it was aggregated on a yearly basis because traffic may fluctuate due to seasonal effects. Only ports handling over one million tons have been kept, because some countries do not release traffic data below this level. The forty-nine excluded ports represent only $0.55 \%$ of total European port traffic in 2006 . A study on the European 
level (Figure 1) is justified by a similar historical background, the context of European integration, and the specificity of European ports compared to other regions of the world (DUCRUET, 2008). Of course, maritime trade and port development greatly differ in nature and magnitude across the continent (CHLOMOUDIS and PALLIS, 2002). The advantage of the data source is the statistical harmonisation across locations.

[Insert Figure 1 about here]

Traffic data was aggregated from 30 to 16 commodity categories for two reasons (Table 3). First, each category corresponds to a specific land-use and cargo handling equipment within the port as well as for shipping and haulage. Second, commodities that did not represent a large traffic volume were aggregated within a larger category in order to avoid the risk of overestimating the specialisation degrees of the few ports handling them. The study of the Le Havre - Hamburg range by CHARLIER (1994) was based on only five commodities, based on the assumption that general cargo is the most valuable traffic (PATTON, 1958). In the end, the 16 commodities represent an exhaustive set covering total European port traffic.

[Insert Table 3 about here]

\subsection{Methodology}

Two main indexes are calculated: the Commodity Diversity Index (CDI) and the Gini coefficient. The CDI is comparable to the Relative Diversity Index proposed by DURANTON and PUGA (2000) and is the inverse of the specialisation coefficient proposed by ISARD (1960). It allows for correcting and comparing differences in commodity shares at the 
European level. For each port, we sum the absolute differences between the share of a commodity $j$ in port $i$ and the share of the corresponding commodity $j$ at European level. The CDI is calculated as follows:

$C D I=\frac{1}{\sum_{j}\left|C_{i j}-C_{j}\right|}$

$C=$ commodity share

$i=1,2, \ldots, n ; j=1,2, \ldots, m)$

The Gini coefficient was chosen as an indicator that more robust to the European average than existing specialisation indexes such as the location quotient used, for instance, by BRITTON (1965), BIRD (1969), VON SCHIRACH-SZMIGIEL (1973), MC CALLA (1979), MARTI (1985) and CHARLIER (1988). This is the first time that this measure of concentration has been applied to the distribution of traffic within ports. The degree of concentration directly highlights to what extent each port's traffic relies on the number of commodities. Therefore, we assume that a high Gini coefficient depicts a high commodity specialisation. Values close to zero indicate a perfect equality while values close to one reveal a high inequality. Formally, we can define the Gini coefficient as follows:

$G_{i}=1-\sum\left(X_{n}-X_{n-1}\right)\left(Y_{n}-Y_{n-1}\right)$

$G_{i}=$ Gini-coefficient of port $i$

$X=$ Cumulative proportion of the commodities when they have equal shares

$Y=$ Cumulative proportion of the share of commodities

$n=1,2, \ldots, 16=$ Commodity shares

The following section analyses the distribution of the new indicators in Europe while examining the specificity if seaports with regard to the four stylised facts retained from the literature. 


\section{Commodity variety at European ports}

4.1 Do diversified and specialised ports coexist?

The distribution of the two indexes (Figure 2) shows that higher diversity concentrates at a few ports, dominantly in the South and in England. Specialised ports are more numerous and widespread, with a tendency to group in southern Italy, Greece, UK, and Scandinavia.

This pattern can be explained by one dominant factor and several secondary factors that combine with each other. The dominant factor is the core-periphery organization of Europe. Southern ports have in common to serve more dispersed local markets or captive hinterlands (e.g. Iberian Peninsula, Greece, Black Sea). Limited access to the rest of the continent and among southern countries (e.g. mountainous and maritime barriers, lack of navigable rivers) and rapid coastal urbanisation since the 1960s (e.g. climatic amenity, tourism) have combined with lower levels of economic welfare (e.g. late inclusion in the EC) to give ports prime importance for developing many regional economies. The spatial discontinuity with mainland Europe also applies to Northern ports, combined with the remoteness from main shipping lanes, small market size, and the scattering of small human settlements outside national capitals partly due to difficult climatic conditions despite higher economic levels. In between those two situations, diversified mainland ports concentrate along the heartland or megalopolis (i.e. Southeast UK, France, Germany, Benelux, and North Italy). Other mainland ports are generally more specialised because traffic is split in order to serve one single and spatially concentrated market or contestable hinterland in a context of regional integration and port competition. Besides this European trend, a number of other local factors may be distinguished:

[Insert Figure 2 about here] 
- Urban magnitude: ports located within large urban agglomerations are more diversified than others; this is the case of national capital cities (e.g. London, Helsinki, Oslo, Copenhagen, Dublin, and Lisbon) and regional cities (e.g. Nantes, Marseilles, Naples, Thessaloniki, Porto-Leixoes, Bilbao, and Barcelona). Thus, traffic variety at such ports directly reflects the economic diversity of their local environment.

- Island effect: several ports located in an island tend to be more diversified because of geographical constraints, as in the case of Heraklion (Crete), Valletta (Malta), and Palma (Mallorca) as well as several British ports (e.g. Liverpool, Tees, Tyne, Forth, Bristol, and Southampton) and Cork in Ireland. Island markets are more concentrated around one single port serving its own captive hinterland.

- Single-port countries: the concentration of traffic at one main gateway (e.g. Constanta, Bourgas, Klaipeda, Koper, and Gdansk-Gdynia) enhances traffic diversity. Comparison of the Baltic countries shows that while Klaipeda is the main port of Lithuania, Tallinn (Estonia) and Riga (Latvia) are less diverse because other ports such as Ventspils and Liepaya handle liquid bulk, notably for Russian transit trade. Such ports also benefit from a lower integration degree of their national transport system with the rest of Europe, allowing maritime transport to keep its competitive advantage over other rail or road transport (JAUERNIG and ROE, 2001).

- Port dispersion: the spatial division of traffic limits traffic concentration among neighbouring ports, as seen in southern Italy, Greece, Sardinia, and in the North Sea. Also, many ports are scattered along Scandinavian coasts and remain highly specialised. This explains why the ports of Cyprus, Sardinia, and some in the UK are all specialised despite the island effect and why Piraeus (Athens) is not as diversified as its urban size would predict. Due to urban site constraints, specialised bulk terminals have shifted outside Piraeus to ensure 
bulk traffic. Therefore, Piraeus tends to specialise in the handling of general cargo and containers.

Specialisation and diversity do not entirely overlap. One commodity may dominate within a diversified portfolio, as seen in the case of oil ports (e.g. Rotterdam, Gdansk, Savona-Vado, Southampton, Copenhagen), container ports (e.g. Algeciras), dry bulk ports (e.g. Dunkirk, Klaipeda), and ro-ro ports (e.g. Dublin). This trend is reinforced by specific local conditions such as industrial complex (e.g. Rotterdam, Dunkirk), container hub strategy (e.g. Maersk ${ }^{7}$ in Algeciras), and urban economy (e.g. Dublin, Copenhagen). Other possible cases are ports with medium specialisation and medium diversity. For instance, London ${ }^{8}$ and Leixoes (Porto) are constrained inland (e.g. lack of hinterland connections) and seaward (e.g. port competition), resulting in a strong local function dedicated to the adjacent economy, and a weaker position towards better positioned ports. Finally, ports with both a low specialisation and a low diversity tend to locate at smaller settlements or more peripheral regions, such as Aveiro, Aviles, Moss, Cuxhaven, Drogheda, and Liepaya. Therefore, traffic variety is much influenced by the territorial environment of seaports.

\subsection{Are larger ports more diversified?}

The relation between traffic volume and traffic diversity (Figure 3) is moderately high (0.34). Rotterdam serves as a good example because it is the biggest port and the most diversified. Ports with higher diversity (CDI > 1) represent only $18 \%$ of the sample but more than $50 \%$ of total European traffic in 2006. Although such results indicate that in general, larger ports are also more diversified, numerous exceptions exist that can be explained by a number of factors: locational and functional. 
Geographical distance to core economic regions plays an important role. Gateways draining wide continental hinterlands combine large throughput volumes and higher diversity, such as the Northern range from Le Havre to Hamburg. Seaports located at regions further from the heartland enjoy an equivalent commodity portfolio as a remedy to distance and inland transport costs. This is the case for many second-order port cities such as Belfast, Cork, Leixoes (Porto), Nantes, Thessaloniki, Bilbao, Gdansk-Gdynia, Liverpool, Gothenburg, Bourgas, and Constanta. This confirms the model of FUJITA and MORI (1996) in which remoteness from core economic regions becomes advantageous if the local hinterland provides sufficient comparative advantages. Some ports serving national capitals are more diversified, but do not generate large traffic volumes due to urban site constraints for local port expansion (e.g. London, Copenhagen, and Oslo).

The functional factor is related to the primacy of one function generating large traffic volume without resulting in high diversity. Container ports such as Gioia Tauro, Taranto, Cagliari, Sines, and Algeciras have been the prime focus of hub-and-spoke strategies of carriers and terminal operators since the 1990s (e.g. Maersk, Port of Singapore Authority), backed by the support of national governments willing to generate profits from the transhipment operations of giant containerships. Oil ports often generate high traffic volume due to the heavy weight of their dominant commodity (e.g. Bergen, Milford Haven, and Augusta), while ferry ports and ro-ro ports have a high traffic frequency on short distances ensuring the continuity of the road network for vehicles (e.g. Calais, Dover, Dublin). The dominant function is exacerbated by a strategic location such as resource field (e.g. offshore), peninsula, strait, or closed sea (e.g. Baltic). Other examples include the capture of specific commodity chains by some large gateways such as Bremerhaven, which is one of the world's largest automobile ports (1.4 million vehicles in 2004). 
[Insert Figure 3 about here]

Thus, specialisation and diversification strategies coexist. Efficient and durable insertion within value-adding commodity chains is possible through both. Yet, it seems that successful specialisation should lead to a diversification process, in order to avoid infrastructure investment being questioned by over-dependence on commodity fluctuations. High diversity can be harmed by diseconomies of scale in large load centres under pressure for competition and expansion. This motivates a look at time dynamics affecting seaport traffic and their commodity variety.

4.3 Are patterns of port hierarchy and commodity variety stable over time?

Despite the shortness of the study period, a look at the cumulated frequency of port traffic based on CDI and GINI between 2000 and 2006 (Table 4) confirms that traffic composition is relatively stable over time. The traffic share of the most diversified ports (over $0.875 \mathrm{CDI}$ ) has regularly decreased from $72 \%$ to $64 \%$, but this is not echoed by an equivalent increase of the share of the most specialised ports, which remained stable around $38 \%$. The traffic share of ports handling over ten million tons in terms of size has remained very stable around $80 \%$, what confirms the overall stability of the hierarchy.

[Insert Table 4 about here]

Another angle of attack is the comparison of traffic growth rates at more diversified and less diversified ports based on their commodity distribution in 2000 (Table 5). ${ }^{9}$ Results show that both diversified and specialised ports enjoy a similar annual level of traffic growth on average. More meaningful is the difference in standard deviations: ${ }^{10}$ more diversified ports 
have more stable growth rates than more specialised ports. Thus, traffic diversity implies stronger resistance against external shocks and fluctuations, which are caused by changes in extra-regional economic factors, and therefore promotes more stable growth rates (ATTARAN, 1984). When a port has a diversification policy, it has more or less a riskspreading strategy. For example, the decrease in the amount of crude oil traffic may be addressed by the attraction of other commodities (e.g. containers), while ports depending mainly on crude oil traffic will face high negative growth rates. Therefore, the amplitude of traffic growth is fundamentally path-dependent. Emerging ports with high growth rates should stabilise while shifting from specialisation to diversity. Of course, smaller ports that fail to attract new cargoes may also have lower growth rates. In the end, commodity specialisation is a necessary stage of port development that is defined by volatile growth, until the port manages to secure its traffic. In any case, ports that managed diversifying their commodity portfolio seem to be the most successful in such strategy avoiding vulnerability. However, such results do not include control variables that are suspected to have some influence on commodity variety, beside traffic itself.

[Insert Table 5 about here]

4.4 The relations between commodity variety and port performance

\subsubsection{Methodology and data presentation}

The relation between commodity variety and port performance is approached through a multiple regression analysis, based on the factors introduced in Table 1 and highlighted in previous sections. In so doing, we use Ordinary Least Squares (OLS) methods to obtain results. The regression models are estimated on the basis of

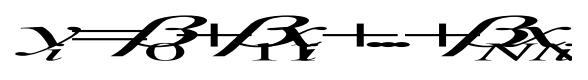


$\mathrm{y}_{\mathrm{i}}$ is defined as the CDI measured in 2006 or the Gini-coefficient for port $i$ in 2006. Thus, we compare the results of an index which is influenced by the European trend and an index which is robust to such trend. We also want to show that the formulation of different indices generally will not lead to different conclusions. We divide our explanatory variables in three groups: port performance indicators, geographical factors, and regional economic factors all presented in Appendix 1. We execute four models. In the first two models we only include the port performance indicators. Certainly there will be an omitted variable bias, more formally:

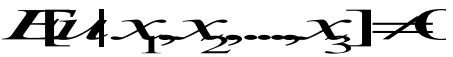

Where $u$ is the error term and $x_{n}$ are the explanatory variables. Therefore in model three and four we explain CDI and GINI also by the geographical and regional economic indicators. The Variance Inflation Factors never exceed the critical value of 10, and therefore there is no severe multicollinearity (KUTNER et al., 2004). When the results of the first two models are in line with the third and fourth models, more robustness is guaranteed. Furthermore, robust standard errors allow for heteroskedasticity and/or the errors are autocorrelated.

\subsubsection{Main results of the multiple regression analysis}

As seen in Table 6, there are no substantial differences in the coefficients of port performance variables between the different models. Because of the omitted variable bias, the coefficients tend to be somewhat larger in model 1 and 2, where geographical and regional indicators are absent. In general, the signs in the different models look plausible and the results of the CDI-models and the GINI-models are in accordance with each other.

Based on the aforementioned hypotheses, it is possible to synthesise the results according to the three main groups of variables. Among port performance indicators, traffic growth does not have a strong impact on commodity variety; its negative sign confirms the previous results showing that more diversified ports enjoy more stable (and often lower) 
growth rates on average, while diversified and specialised ports have very similar growth patterns. Total traffic is only significant in influencing CDI. So, larger ports are generally more diversified although this only holds for the relative index. More interesting is the share of outbound traffic that is in all models very significant. This indicates that dominant outbound flows negatively influence variety. Indeed, a number of specialised ports and terminals are dedicated to the export of local resources (e.g. oil, minerals, wood) and remain plant-based, such as oil terminals operated by one single company. Dominant import flows at European ports highlight an advantageous position with regard to hinterland distribution of diversified markets. In addition, large load centres such as Rotterdam and Antwerp tend to keep a balanced traffic distribution due to their mix of imports and exports. The share of international traffic does not significantly lead to a more or less diverse commodity portfolio, because smaller or more specialised ports may be fully international such as Shoreham in UK exporting grains to the continent. Because many ports provide ro-ro services connecting another country, they are considered international should they be specialised or diversified. The maritime degree is positively related to CDI and negatively related with GINI. Thus, a $1 \%$ increase in the number connections will lead to a change in CDI and GINI of respectively 0.0868 and -0.0833 . This is an intuitive result: more connections signify a greater variety of forelands and hinterlands, or intermediacy and centrality (FLEMING and HAYUTH, 1994), which will result in greater commodity variety and full-fledged trading ports. Hub centrality is only slightly significant in model (4). This sign is somewhat counterintuitive, since we expected that a more central hub would be more diversified (e.g. Rotterdam as a hub platform for UK). A reason for this can be that specialised container ports such as Algeciras and Gioia Tauro are also central hubs in the Mediterranean. While port performance indicators explain the largest part of the diversity or specialisation in a port in all models, the higher value of the 
$\mathrm{R}^{2}$ in models (3) and (4) indicates that CDI and GINI are somewhat better explained by adding regional and geographical variables.

[Insert Table 6 about here]

Geographical indicators indeed are also very important explaining commodity variety, as it was suggested in Figure 2. Although their impact is not very significant due to the juxtaposition of very different ports within a densely occupied continent, the model (4) confirms that Southern and Eastern ports tend to be more diversified. Many Scandinavian ports have relatively narrowed hinterlands or are dedicated to specific commodities or firms based on local resources, such as Narvik in Norway (iron ore) and Sullom Voe in Scotland (oil). Another example is Groningen in the Netherlands where the current development strategy is based on energy exploitation of North Sea offshore gas fields. One very significant factor is the distance to a larger city; it is positively related to CDI and negatively to GINI. This indicator of urban centrality implies that the dimension of the port city's gravitational area highly contributes to diversity, due to an advantageous position in the European urban system. This distance is also influenced by natural factors such as remoteness from main economic regions, as seen in Appendix 2. Ports located at cities with limited radiance are often more specialised, because they are bounded to a local hinterland. Thus, distance to the nearest larger city is influent in various ways: it may translate centrality or remoteness according to the local and regional contexts. This is why it is crucial to include urban population to correct for this complexity. Urban size has a positive impact on commodity variety: an increase in $1 \%$ of the urban population will lead to a change in CDI and GINI of respectively 0.0285 and -0.0174 . This confirms previous intuitions that ports located within larger agglomerations often handle more varied cargoes to cover the needs of the adjacent 
city. Comparatively, population density and the island dummy appear to have no significant effect. The sign of the coefficient of the island dummy confirms that ports located on islands tend to be somewhat more diversified than mainland ports because they often serve a captive hinterland. The negative sign for population density in model (3) may corroborate the problem of land scarcity around some port areas, but the value is not significant enough to be considered.

Finally, regional economic factors show disappointing results, probably because data is collected at NUTS2 level due to limited availability at NUTS3 level. A bigger regional economy (GDP) does not significantly result in more diversity or specialisation. In fact, many ports serve as transit trade platforms for distant hinterlands regardless of the nature of their regional economy, such as Baltic ports for Russian oil, Le Havre for the Paris basin, and even Rotterdam for the Rhine-Ruhr region. Furthermore, most economic sectors contribute to specialisation, although their effect is relatively small. For instance, an increase in $1 \%$ of employment in the construction sector shall lead to a decrease in CDI of 0.0148 and an increase in the GINI of 0.0052 . An increase in the trade and transport sector will lead to a slight decrease in the CDI. Finally, an increase in the advanced producer services and public services sector will also lead to a decrease in commodity variety. Such facts may suggest that too much regional specialisation creates port traffic specialisation due to the concentration of demand on a narrow set of commodities (e.g. bulk for construction). Further research may specifically look at how regional economic variety and port traffic variety are interrelated, but that is beyond the scope of this paper.

Overall, the hypothesis of this research was that variety and port performance are in some way related to each other. This hypothesis is confirmed, since several key dimensions (e.g. traffic volume, urban centrality, flow balance, maritime degree, and regional economy) 
influence commodity variety. A brief overlook at how specific commodities relate with such dimensions is proposed next.

\subsection{The role of specific commodities}

Although the linear correlations among main variables (Table 7) do not account for circular causality, they confirm existing assumptions reviewed in section 2.

Unsurprisingly, containers have significant correlation with maritime degree and hub centrality. General cargo and containers have a positive relation with inbound flows, which is a major component of commodity diversity as seen in the regression. Containers have the highest correlation with urban population and distance to nearest bigger city, showing that container movements tend overlapping the spatial structure of the European urban system, where populations have a strong demand for manufactured imports, notably from Asia. Therefore, the apparent territorial complexity of ever-changing logistics systems shall not hide that in the end, containers concentrate nearby their raison-d'être: human settlements (DUCRUET, 2008). Also important is the correlation of urban indicators with general cargoes (e.g. employment and local industries), and dry bulks (e.g. construction materials). Traffic growth is negatively related with many liquid bulks, probably due to their fluctuations both in terms of price and quantity on the world market, while dry bulks have a low but positive correlation with growth (e.g. coal).

In the end, CDI itself is better related with refined oil and most liquid bulks, but also with containers. This may highlight the current overlap of different time frames of port development. The coastal concentration of heavy industries around port areas in the 1960s (i.e. the so-called Maritime Industrial Development Areas or MIDAs) has been a very important stage of specialisation in bulk traffic, resulting in the development of large petrochemical complexes at estuarine locations. Based on this stage and on the benefits of 
concentration despite the crisis of the 1970s, further development has taken place extending to other commodities of which containers. Although nowadays liquid bulk is not likely to be the key element of traffic diversification, the development of containers at former (or current) liquid bulk ports is a good example of path-dependency and self-organisation in human geography. However, successive centrally-planned strategies taking place at remotely located Southern ports have been unevenly successful, such as Marseilles-Fos, Huelva, Sines, Gioia Tauro, and Taranto. As seen in Appendix 2, average change of CDI between 2000 and 2006 is noticeably positive for many ports in transition economies (e.g. Romania, Poland, Bulgaria). Because socialist ports were traditionally specialised in providing inland heavy industries with bulk products (DUCRUET et al., 2009), the shift from one socialist hinterland to independent republics in the early 1990s ultimately resulted in traffic reorganisation and diversification through port competition and concentration (THOREZ, 1998). Thus, containerisation has spread from North to South and to the East at different time periods. One last aspect is functional: diversification (average CDI change) is negatively related with vehicle traffic and liquefied gas (liquid bulk). Those two commodity types have in common to be less sticky for other commodities because they tend using the port mostly as a transit point (e.g. pipelines, ferry transfers of cars and trucks), while diversification is positively related with ores (solid bulk) and iron and steel (general cargo), which foster economies of scale for various industries that, in turn, generate demand for other commodities. More research is needed about the interplay of port development and commodity diversification dynamics to strengthen such results. Nevertheless, commodity diversification seems to depict a gradual adaptation to changing technological and geopolitical cycles through local policies rather than a rigid, ubiquitous, and predictable process of evolution from one commodity to another.

[Insert Table 7 about here] 


\section{Conclusion}

This research has linked the case of seaports to more general theories about the development of countries, regions, and cities. It has confirmed that seaports are not 'aberrant cases' (BIRD, 1970) in economic geography. Indeed, the European port system is organised according to a hierarchy in which few larger ports concentrate a large share of total traffic.

How are ports different from cities? With reference to the synthetic work of DURANTON and PUGA (2000), four main stylised facts applying to cities and regions are verified in the case of seaports based on a review of existing literature and on a statistical analysis of available data across Europe. Main results confirm the importance of demographic size, traffic balance, accessibility to and distance from core economic regions, and position in maritime networks. Such evidence echoes the port triptych model (hinterland-port-foreland) proposed by VIGARIE (1979) three decades ago, which was criticised due to the apparent complexity of contemporary transport systems. In the end, this paper reveals the importance of regional variations across Europe for both general models and unique situations.

The main implication of the research for policy is twofold: port competition mechanisms, and the territorial dimension of port development. In terms of competition for chain capture, already established load centres and gateways tend to be better suited for maintaining and expanding their commodity portfolio, based upon the efficient integration of strong hinterland and maritime connections. Smaller ports are constrained when attempting to reach a higher position in the hierarchy. This apparent determinism should not ignore, however, the challenge of peripheral ports (HAYUTH 1981) that stems from the combined action of governments (e.g. port planning, transport policy) and firms (e.g. search for lower costs, network expansion) in a context of regional integration and diseconomies of scale in large load centres. 
Second, as suggested by the trend of port devolution in France and Canada (DEBRIE et al., 2007), the activity of small and medium-sized ports should not be limited to competition issues. Not every port can pretend having a continental dimension. Despite the apparent spatial flexibility and complexity of contemporary transport chains, our results indicate a durable influence of the territorial context in which ports operate. Thus, ports are not only embedded in global value chains but also in urban and regional spatial structures that both fix and constrain their evolution. It is therefore the task of interested parties to ensure that a strong dependence on few commodities shall not harm too much not only port activities themselves, but also local economies depending on the port. Recent evolutions in the port industry and the call for greener gateways (COMTOIS and SLACK, 2009) shall motivate port players improving the quality of their infrastructure and equipments rather than continuously expanding existing capacity.

Further research shall be oriented towards four main directions. First, the research shall compare European trends with other regions of the world where equivalent data sources are available, such as the United States and Japan. Second, refining regional indicators would allow a more in-depth study of the interdependence between commodity variety, port performance, regional economic variety, and regional economic growth. Third, processes of traffic diversification may be better understood when analysed through an evolutionary approach over a longer time period: ${ }^{11}$ how path-dependent is the shift from one commodity to several commodities? One interesting research direction is about the determinants of successful innovation spread and adoption, notably in the case of containerisation diffusion amongst bulk and general cargo ports from the 1970s onwards (e.g. diffusion through hierarchy, spatial or functional proximity, etc.). Fourth, a stronger collaboration with the port industry, of which port authorities are prominent, would benefit from such research agenda. 


\section{Acknowledgements}

The authors would like to thank Prof. Denise Pumain (University of Paris-I Sorbonne) and

Mr. Willeumier (Port of Rotterdam) for their useful comments. Thanks also go to the three anonymous reviewers whose remarks helped improving this paper, as well as to Anette Lodestijn, editorial assistant, for her very kind support. This research has benefited from EU financial support through the Marie Curie EIF-FP6 programme and reintegration grant.

\section{References}

AIRRIESS C. (1989) The spatial spread of container transport in a developing regional economy: North Sumatra, Indonesia, Transportation Research A 23, 453-61.

AIRRIESS C. (2001) The regionalization of Hutchison Port Holdings in mainland China, Journal of Transport Geography 9, 267-78.

ARROW K. J. (1962) The economic implications of learning by doing, Review of Economic Studies 29, 155-73.

ATTARAN M. (1984) Industrial diversity and economic performance in U.S. areas, Annals of Regional Science 20, 44-54.

BIRD J. (1963) The Major Seaports of the United Kingdom, Hutchinson, London.

BIRD J. (1969) Traffic flows to and from British seaports, Geography 54, 284-301.

BIRD J. (1970) Seaports are not aberrant cases, Area 4, 65-8.

BLIEN U., SUEDEKUM J. and WOLF K. (2006) Local employment growth in West Germany: a dynamic panel approach, Labour Economics 13, 445-58.

BRITTON J. N. H. (1965) Coastwise external relations of the ports of Victoria, The Australian Geographer 9, 269-81.

BRUNET R. (1989) Les Villes Européennes, DATAR, Paris. 
BRUNET R. (Ed) (1993) Les Mots de la Géographie, Dictionnaire Critique, La Documentation Française, Paris.

BUN M. J. G. and EL MAKHLOUFI A. (2007) Dynamic externalities, local industrial structure and economic development: panel data evidence for Morocco, Regional Studies 41, 823-37.

CARTER R. E. (1962) A comparative analysis of United States ports and their traffic characteristics, Economic Geography 38, 162-75.

CARTIER C. (1999) Cosmopolitics and the maritime world city, The Geographical Review 89, 278-89.

CHARLIER J. (1988) Structural change in the Belgian port system, 1980-1986, Maritime Policy and Management 15, 315-26.

CHARLIER J. (1994) Sur le concept de tonnages pondérés en économie portuaire. L'exemple du Northern Range, Les Cahiers Scientifiques du Transport 29, 75-84.

CHLOMOUDIS C. I. and PALLIS A. A. (2002) European Union Port Policy: The Movement Towards a Long-Term Strategy, Edward Elgar, Cheltenham.

CHRISTALLER W. (1933) Die Zentralen Orte in Süddeutschland, Iena University, Iena.

CLARK C. (1945) The economic functions of a city in relation to its size, Econometrica 13, 97-113.

COMBES P. P. (2000) Economic structure and local growth, Journal of Urban Economics 47, $329-55$.

COMTOIS C. and SLACK B. (2009) Competitiveness of green gateways: a blueprint for Canada, in NOTTEBOOM, T. E., DuCRUET, C., DE LANGEN, P. W., (Eds) Ports in Proximity: Essays on Competition and Coordination among Adjacent Seaports, Ashgate, Aldershot (forthcoming). 
DE LANGEN P. W. (1998) The future of small and medium sized ports in Europe, in SCIUTTO G. and BREBBIA C. A. (Eds) Maritime Engineering and Ports, pp. 263-79. Boston \& Southampton, WIT Press.

DE LANGEN P. W. (2003) The performance of seaport clusters, ERIM PhD Series Research in Management No. 34, Erasmus University, Rotterdam.

DE LANGEN P. W. (2007) Port competition and selection in contestable hinterlands; the case of Austria, European Journal of Transport Infrastructure Research 7, 1-14.

DE LUCIO J. J., HERCE J. J. and GOICOLEA A. (1996) Externalities and industrial growth: Spain 1978-1992, Working Paper No. 96-14, FEDEA and Universidad Complutense de Madrid.

DE LUCIO J. J., HERCE J. J. and GOICOLEA A. (2002) The effects of externalities on productivity growth in Spanish industry, Regional Science and Urban Economics 32, 241-58. DE VOR F. and DE GROOT H. L. F. (2008) Agglomeration externalities and localised employment growth: the performance of industrial sites in Amsterdam, Tinbergen Institute Discussion Paper No. 2008-033/3, Erasmus University Rotterdam.

DEBRIE J., GOUVERNAL E. and SLACK B. (2007) Port devolution revisited: the case of regional ports and the role of lower tier governments, Journal of Transport Geography 15, 455-64.

DICKEN P., KELLY P. F., OLDS K., and YEUNG H. (2001) Chains and networks, territories and scales: towards a relational framework for analysing the global economy, Global Networks 1, 89-112.

DUCRUET C. (2008) World typology of city-port relationships, Cybergeo: European Journal of Geography 417, http://www.cybergeo.eu/index17332.html (Accessed January 2009). 
DUCRUET C. (2009) Port regions and globalization, in NOTTEBOOM, T. E., DUCRUET, C., DE LANGEN, P. W., (Eds) Ports in Proximity: Essays on Competition and Coordination among Adjacent Seaports, Ashgate, Aldershot (forthcoming).

DUCRUET C. and JO J. C. (2008) Coastal cities, port activities and logistic constraints in a socialist developing country: the case of North Korea, Transport Reviews 28, 1-25.

DUCRUET C. and LEE S. W. (2006) Frontline soldiers of globalisation: port-city evolution and regional competition, Geojournal 67, 107-22.

DUCRUET C., ROUSSIN, S. and JO J. C. (2009) Going West? Spatial polarization of the North Korean port system, Journal of Transport Geography (forthcoming).

DUCRUET C. and VAN DER HORST M. R. (2009) Transport integration at European ports: measuring the role and position of intermediaries, European Journal of Transport Infrastructure Research 9, 121-42.

DURANTON G. and PUGA D. (2000) Diversity and specialisation in cities: why, where and when does it matter? Urban Studies 37, 533-55.

FLEMING D. K. and HAYUTH Y. (1994) Spatial characteristics of transportation hubs: centrality and intermediacy, Journal of Transport Geography 2, 3-18.

FLORIDA R. L. (2004) The Rise of the Creative Class, Basic Books, New York NY.

FORWARD C. N. (1984) The overwhelming dominance of the port of Vancouver on Canada's West coast, in HOYLE, B. S., HILling, D. (Eds) Seaport Systems and Spatial Change, pp. 343-60. John Wiley and Sons, Chichester.

FRENKEN K., VAN OORT F. and VERBURG T. (2007) Related variety, unrelated variety, and regional economic growth, Regional Studies 41, 685-97.

FUJITA M., KRUGMAN P. and VENABLES A. J. (Eds) (1999) The Spatial Economy: Cities, Regions, and International Trade, MIT Press, Cambridge MA. 
FUJITA M. and MORI T. (1996) The role of ports in the making of major cities: selfagglomeration and hub-effect, Journal of Development Economics 49, 93-120.

GEREFFI G. and KORZENIEWICZ M. (Eds) (1994) Commodity Chains and Global Capitalism, Praeger, Westport.

GLAESER E. L., KALLAL H. D., SCHEINKMAN J. A. and SHLEIFER A. (1992) Growth in cities, Journal of Political Economy 100, 1127-52.

GOSS R. (1990) Economic policies and seaports (1) The economic functions of seaports, Maritime Policy and Management 17, 207-19.

HAEFNER L. E., LANG D. E. and CRONIN T. (1980) Forecast of key commodity flows at a regional port, Transportation Research Record 763, 2-5.

HAEZENDONCK E., COEK C. and VERBEKE A. (1999) Value Added Analysis (VAA) as a tool for strategic port planning, Bulletin of the Permanent International Association of Navigation Congresses 100, 28-68.

HANAPPE P. and SAVY M. (1981) Industrial port areas and the Kondratieff cycle, in HOYLE B. S. and PINDER D. A. (Eds) Cityport Industrialization and Regional Development, pp. 11-21. Pergamon Press, New York.

HAYUTH Y. (1981) Containerization and the load center concept, Economic Geography 57, $161-76$.

HENDERSON J. V. (1988) Urban Development: Theory, Fact and Illusion, Oxford University Press, Oxford.

HENDERSON J. V., KUNCORO A. and TURNER M. (1995) Industrial development in cities, Journal of Political Economy 103, 1067-85.

HENDERSON J. V. (1997a) Externalities and industrial development, Journal of Urban Economics 42, 449-70. 
HENDERSON J. V. (1997b) Medium size cities, Regional Science and Urban Economics 27, 583-612.

HENDERSON J. V. (1999) Marshall's economies, Working Paper No. 7358, National Bureau of Economic Research.

HOYLE B. S. (1989) The port-city interface: trends, problems, and examples, Geoforum 20, 429-35.

ISARD W. (1960) Methods of Regional Analysis: An Introduction to Regional Science, MIT Press, Cambridge.

JACOBS J. (1969) The Economy of Cities, Random House, New York.

JACOBS W. and HALL P. V. (2007) What conditions supply chain strategies for ports? The case of Dubai, Geojournal 68, 327-42.

JACOBS W., DUCRUET C. and DE LANGEN P. W. (2009) Integrating world cities into global production networks: the case of port cities, Global Networks (forthcoming).

KAPLINSKY R. (2004) Sustaining income growth in a globalizing world: the search for the Nth rent, Working Paper, University of Brighton, Brighton.

KENYON J. B. (1970) Elements in inter-port competition in the United States, Economic Geography 46, 1-24.

KUBY M. and REID N. (1992) Technological change and the concentration of the U.S. general cargo port system: 1970-88, Economic Geography 68, 272-89.

KUTNER M. H., NACHTSHEIM C. J., NETER J. and LI W. (2005) Applied Linear Regression Models. McGraw-Hill, New York.

LAWTON R. and LEE R. W. (Eds) (2002) Population and Society in Western European Port Cities, c. 1850-1939, Liverpool University Press, Liverpool.

LEE S. W., SONG D. W. and DUCRUET C. (2008) A tale of Asia's world ports: the spatial evolution in global hub port cities, Geoforum 39, 372-85. 
LEMARCHAND A. and JOLY O. (2009) Regional integration and maritime range, in NotTeboOM, T. E., DUCRUET, C., DE LANGEN, P. W., (Eds) Ports in Proximity: Essays on Competition and Coordination among Adjacent Seaports, Ashgate (forthcoming).

LESLIE D. and REIMER S. (1999) Spatializing commodity chains, Progress in Human Geography 23, 401-20.

LOYEN R., BUYST E. and DEVOS G. (Eds) (2003) Struggling for leadership: AntwerpRotterdam port competition between 1870-2000, Physica-Verlag, Heidelberg and New York.

LUDEMA R. D. (2001) The return of dependency theory: is primary commodity specialization bad for development? USITC International Economic Review 3466, 17-24.

MARSHALL A. (1890) Principles of Economics, Macmillan, London.

MARTI B. E. (1985) Chilean ports: commodity specialization and potential for containerization, Professional Geographer 37, 320-28.

MAUREL F. (1996) Evolution locale de l'industrie 1982-1992 et convergence régionale: quelques résultats empiriques sur données françaises, Document de travail de la Direction de la Prévision No. 96-6. Ministère de l'Economie des Finances et de l'Industrie, Paris.

MAYER H. M. (1973) Some geographic aspects of technological change in maritime transportation, Economic Geography 49, 145-55.

MC CALLA R. (1979) Specialization and economic impact of the ports of Montreal, Quebec, Saint John, and Halifax, Maritime Policy and Management 6, 285-92.

MC CANN P. (2001) Urban and Regional Economics, Oxford University Press, New York. O’SULLIVAN A. (2003) Urban Economics, McGraw-Hill/Irwin, Boston MA.

OTTAVIANO G. I. P. and PERI G. (2006) The economic value of cultural diversity: evidence from US cities, Journal of Economic Geography 6, 9-44.

PATTON D. J. (1958) General cargo hinterlands of New York, Philadelphia, Baltimore, and New Orleans, Annals of the Association of American Geographers 48, 436-55. 
PAULUS F. (2004) Coévolution dans les Systèmes de Villes : Croissance et Spécialisation des Aires Urbaines Françaises de 1950 à 2000, Unpublished PhD Dissertation, Paris.

PUMAIN D. (1982) La Dynamique des Villes, Economica, Paris.

PUMAIN D. and FAVARO J. M. (2008) Urban hierarchies explained by a spatial interaction model including innovation cycles, Paper presented at the Annual Conference of the Association of American Geographers, Boston MA, April 15-19.

QUIGLEY, J. M. (1998) Urban diversity and economic growth, Journal of Economic Perspectives 12, 127-38.

ROMER P. M. (1986) Endogenous technology change, Journal of Political Economy 98, 71 102.

ROZENBLAT C. and CICILLE P. (2003) Les Villes Européennes : Analyse Comparative, DATAR, Paris.

ROZENBLAT C. (Ed) (2004) Comparer les Villes Portuaires en Europe, Maison de la Géographie, Montpellier.

SHARPLESS J. B. (1976) The economic structure of port cities in the mid-nineteenth century: Boston and Liverpool, 1840-1860, Journal of Historical Geography 2, 131-43.

STERN E. and HAYUTH Y. (1984) Developmental effects of geopolitically located ports, in HOYLE B. S. and HILLING D. (Eds) Seaport Systems and Spatial Change, pp. 239-49. John Wiley and Sons, Chichester.

TABUSHI T. and THISSE J. F. (2002) Regional specialization and transport costs, Discussion Paper 3542, Centre for Economic Policy Research, http://www.cepr.org/pubs/dps/DP3542.asp

TAYLOR P. J., WALKER D. R. F., CATALANO G. and HOYLER M. (2002) Diversity and power in the world city network, Cities 19, 231-41. 
TODD D. (2000) Retreat from specialisation: a coal port's search for sustainability, The Journal of Transport History 21, 168-90.

TODD D. (2003) Ore imports and port competition: a Cumbrian struggle for supremacy, The Journal of Transport History 24, 22-37.

VAN OORT F. G., VAN SOEST P. and GERKING S. D. (2005) Dynamic information externalities and employment growth in the Netherlands, in BOSCHMA R. A. and KLOOSTERMAN R. C. (Eds) Learning from Clusters: a Critical Assessment from an Economic-Geographical Perspective, pp. 303-32. Springer, The Netherlands.

VIGARIÉ A. (1979) Ports de Commerce et Vie Littorale, Hachette, Paris.

VON SCHIRACH-SZMIGIEL C. (1973) Trading areas of the United Kingdom ports, Geografiska Annaler 55B, 71-82.

WANG J. J., OLIVIER D., NOTTEBOOM T. E. and SLACK B. (Eds) (2007) Ports, Cities, and Global Supply Chains, Ashgate, Aldershot.

WEIGEND G. G. (1958) Some elements in the study of port geography, Geographical Review 48, 185-200. 
Table 1: Port specialisation and diversification factors

\begin{tabular}{|c|c|c|}
\hline Level & Specialisation & Diversification \\
\hline $\begin{array}{c}\text { Global / } \\
\text { International }\end{array}$ & $\begin{array}{l}\text { - Dedicated transhipment hubs (e.g. Maersk, } \\
\text { Algeciras) } \\
\text { - Peripheral port challenge, new port } \\
\text { development } \\
\text { - Technological revolutions (e.g. } \\
\text { containerization) }\end{array}$ & $\begin{array}{l}\text { - Insertion in new commodity chains (e.g. } \\
\text { automobile) } \\
\text { - Globalization of production networks (e.g. } \\
\text { manufacturing) } \\
\text { - Vertical integration of ocean carriers, terminal } \\
\text { operators, forwarders }\end{array}$ \\
\hline $\begin{array}{l}\text { Regional / } \\
\text { National }\end{array}$ & $\begin{array}{l}\text { - Spatial division of traffic in centralized countries } \\
\text { (e.g. France, South Korea), national port policy } \\
\text { - } \quad \text { Lock-in (or tunnel) effect of inland core regions } \\
\text { concentrating economic activities } \\
\text { - } \quad \text { Preferential cross-border traffic (e.g. transit } \\
\text { trade, short-sea shipping, ro-ro) }\end{array}$ & $\begin{array}{l}\text { - Geographical remoteness, island effect (e.g. } \\
\text { Malta) } \\
\text { - Port system concentration at one main load } \\
\text { centre } \\
\text { - Large continental hinterland, wide foreland } \\
\text { connections }\end{array}$ \\
\hline Local & $\begin{array}{l}\text { - Port-city separation, shift of terminals from } \\
\text { urban core, lack of space for further port expansion } \\
\text { - Port cluster, MIDA, plant-based development } \\
\text { (e.g. energy, petrochemicals) } \\
\text { - Resource-based development (e.g. agriculture, } \\
\text { forestry, mining) }\end{array}$ & $\begin{array}{l}\text { - Urban agglomeration, coastal economic } \\
\text { concentration } \\
\text { - Intermodal connections, physical and } \\
\text { managerial transport integration } \\
\text { - Free-zone, growth pole, and on-site logistics } \\
\text { (value-added) development }\end{array}$ \\
\hline
\end{tabular}

Source: authors 
Table 2: Empirical evidence on specialisation, diversity, and growth

\begin{tabular}{|l|c|c|c|}
\hline \multicolumn{1}{|c|}{ Authors } & Country & $\begin{array}{c}\text { Specialisation } \\
\text { spurs growth }\end{array}$ & $\begin{array}{c}\text { Diversity spurs } \\
\text { growth }\end{array}$ \\
\hline Glaeser et al. (1992) & USA & -1 & +1 \\
Henderson et al. (1995) & USA & +1 & +1 \\
De Lucio et al. (1996) & Spain & -1 & +1 \\
Maurel (1996) & France & +1 & +1 \\
Henderson (1997a) & USA & +1 & +1 \\
De Lucio et al. (2002) & Spain & -1 & 0 \\
Combes (2000) & France & -1 & +1 \\
Van Oort et al. (2005) & The Netherlands & 0 & +1 \\
Blien et al. (2006) & Germany & 0 & 0 \\
Frenken et al. (2007) & The Netherlands & +1 & +1 \\
Bun \& El Makhloufi (2007) & Morocco & -1 & 0 \\
De Vor \& De Groot (2008) & The Netherlands & -1 & +8 \\
\hline \multicolumn{2}{|r|}{} & Total & \\
\hline
\end{tabular}

Source: Adapted from Bun and El Makhloufi (2007)

N.B. $-1=$ negative effect $; 0=$ ambivalent, inconclusive $;+1=$ positive effect 
Table 3: European port traffic by commodity, 2006

\begin{tabular}{|c|c|c|c|c|c|}
\hline Main categories & $000^{\prime}$ tons & $\%$ & Detailed categories & $000^{\prime}$ tons & $\%$ \\
\hline \multirow{4}{*}{ Liquid bulk } & \multirow{4}{*}{$1,549,240$} & \multirow{4}{*}{40.65} & Liquefied gas & 75,998 & 1.99 \\
\hline & & & Crude oil & 722,299 & 18.95 \\
\hline & & & Refined oil products & 614,724 & 16.13 \\
\hline & & & Other or unspecified liquid bulk goods & 136,219 & 3.57 \\
\hline \multirow{4}{*}{ Dry bulk } & \multirow{4}{*}{976,303} & \multirow{4}{*}{25.61} & Ores & 228,464 & 5.99 \\
\hline & & & Coal & 289,430 & 7.59 \\
\hline & & & Agricultural products & 126,980 & 3.33 \\
\hline & & & Other or unspecified dry bulk goods & 331,429 & 8.70 \\
\hline \multirow{2}{*}{ Containers } & \multirow{2}{*}{613,971} & \multirow{2}{*}{16.11} & Freight units $<40-\mathrm{ft}$ & 269,386 & 7.07 \\
\hline & & & Freight units $>40-\mathrm{ft}$ & 344,585 & 9.04 \\
\hline \multirow{3}{*}{ Roll-on / roll-off } & \multirow{3}{*}{421,946} & \multirow{3}{*}{11.07} & Self-propelled vehicles & 245,695 & 6.44 \\
\hline & & & Non self-propelled vehicles & 141,002 & 3.70 \\
\hline & & & Rail wagons, shipborne trailers, etc. & 35,294 & 0.93 \\
\hline \multirow{3}{*}{ General cargo } & \multirow{3}{*}{249,967} & \multirow{3}{*}{6.56} & Forestry products & 58,877 & 1.54 \\
\hline & & & Iron \& steel products & 97,736 & 2.56 \\
\hline & & & Other or unspecified general cargo & 93,354 & 2.45 \\
\hline Total & $3,811,531$ & 100.00 & Total & $3,811,531$ & 100.00 \\
\hline
\end{tabular}

Source: calculated by authors based on Eurostat 
Table 4: Cumulated frequency of traffic volume, 2000-2006

\begin{tabular}{|c|c|ccccccc|}
\hline Variable & Values & 2000 & 2001 & 2002 & 2003 & 2004 & 2005 & 2006 \\
\hline \multirow{6}{*}{ CDI } & $>1.000$ & $53.9(50)$ & $55.3(50)$ & $53.7(61)$ & $54.7(61)$ & $49.2(61)$ & $51.3(65)$ & $50.6(59)$ \\
& $>0.875$ & $18.1(40)$ & $19.3(38)$ & $18.1(37)$ & $11.5(37)$ & $15.1(37)$ & $14.8(40)$ & $13.7(49)$ \\
& $>0.750$ & $9.4(51)$ & $11.7(62)$ & $11.4(69)$ & $16.4(76)$ & $18.1(73)$ & $16.6(78)$ & $18.3(76)$ \\
& $>0.625$ & $12.5(62)$ & $10.4(59)$ & $10.9(69)$ & $10.7(68)$ & $11.4(79)$ & $11.0(77)$ & $10.3(81)$ \\
& $>0.380$ & $6.1(41)$ & $5.7(44)$ & $6.0(50)$ & $6.7(54)$ & $6.3(53)$ & $6.2(60)$ & $7.1(65)$ \\
\hline \multirow{6}{*}{ GINI } & $>0.845$ & $18.3(75)$ & $17.6(75)$ & $20.8(88)$ & $19.6(91)$ & $21.6(99)$ & $21.2(106)$ & $20.3(112)$ \\
& $>0.753$ & $20.1(76)$ & $18.6(73)$ & $18.1(81)$ & $19.5(84)$ & $18.1(86)$ & $16.2(86)$ & $17.3(89)$ \\
& $>0.661$ & $27.3(68)$ & $31.2(69)$ & $24.8(75)$ & $28.7(82)$ & $27.1(77)$ & $27.9(83)$ & $29.1(94)$ \\
& $>0.568$ & $26.0(28)$ & $24.3(30)$ & $27.8(34)$ & $23.4(31)$ & $23.7(33)$ & $26.8(39)$ & $24.3(27)$ \\
& $>0.476$ & $8.3(6)$ & $8.3(6)$ & $8.4(8)$ & $8.7(8)$ & $9.4(10)$ & $8.0(8)$ & $9.0(8)$ \\
& $>25,000$ & $54.2(29)$ & $53.8(30)$ & $54.4(35)$ & $55.0(37)$ & $53.6(35)$ & $53.2(35)$ & $55.1(38)$ \\
& $>10,000$ & $24.6(43)$ & $25.8(48)$ & $24.8(51)$ & $24.0(52)$ & $25.7(57)$ & $26.1(59)$ & $23.5(55)$ \\
SIZE & $>5,000$ & $9.7(36)$ & $8.2(32)$ & $8.0(35)$ & $9.1(43)$ & $9.2(46)$ & $8.8(46)$ & $10.0(55)$ \\
& $>2,000$ & $8.9(79)$ & $9.2(81)$ & $9.5(93)$ & $8.9(94)$ & $8.7(95)$ & $8.9(99)$ & $8.2(53)$ \\
& $>0,000$ & $2.7(57)$ & $3.0(62)$ & $3.3(76)$ & $3.0(72)$ & $2.8(72)$ & $3.1(83)$ & $3.2(129)$ \\
\hline
\end{tabular}

Source: realised by authors based on Eurostat

N.B. Number of ports is in parentheses 
Table 5: Commodity variety and traffic growth

\begin{tabular}{|c|c|ccccc|}
\hline \multicolumn{1}{|c|}{} & & \# of ports & Minimum & Maximum & Mean & Standard Deviation \\
\hline \multirow{6}{*}{ CDI } & $>1.000$ & 49 & -0.06 & 0.13 & 0.0206 & 0.0354 \\
& $>0.883$ & 33 & -0.04 & 0.12 & 0.0323 & 0.0378 \\
& $>0.765$ & 45 & -0.05 & 0.12 & 0.0216 & 0.0406 \\
& $>0.648$ & 62 & -0.11 & 0.32 & 0.0291 & 0.0719 \\
& $>0.531$ & 51 & -0.05 & 0.20 & 0.0301 & 0.0557 \\
\cline { 2 - 7 } & $>0.785$ & 121 & -0.06 & 0.13 & 0.0247 & 0.0383 \\
& $>0.785$ & 120 & -0.11 & 0.32 & 0.0292 & 0.0637 \\
\hline \multirow{6}{*}{ GINI } & $>0.841$ & 78 & -0.11 & 0.32 & 0.0250 & 0.0643 \\
& $>0.745$ & 71 & -0.07 & 0.29 & 0.0303 & 0.0544 \\
& $>0.649$ & 57 & -0.05 & 0.13 & 0.0282 & 0.0394 \\
& $>0.553$ & 29 & -0.06 & 0.11 & 0.0183 & 0.0372 \\
& $>0.457$ & 5 & 0.01 & 0.05 & 0.0297 & 0.0126 \\
\cline { 2 - 7 } & $>0.780$ & 121 & -0.11 & 0.32 & 0.0278 & 0.0628 \\
& $>0.780$ & 120 & -0.07 & 0.13 & 0.0255 & 0.0391 \\
\hline
\end{tabular}

Source: realised by authors based on Eurostat 
Table 6: Results of the OLS regression

\begin{tabular}{|c|c|c|c|c|}
\hline \multicolumn{5}{|c|}{$\begin{array}{c}\text { Coefficients } \\
\text { (Robust standard errors) }\end{array}$} \\
\hline & (1) CDI2006 & (2) GINI2006 & (3) CDI2006 & (4) GINI2006 \\
\hline \multicolumn{5}{|l|}{ Port performance indicators } \\
\hline CAGR 05-06 & $\begin{array}{r}-0.0751 \\
(0.0629)\end{array}$ & $\begin{array}{r}0.0121 \\
(0.0252)\end{array}$ & & \\
\hline Total traffic [LOG] & $\begin{array}{r}0.2106^{* * *} \\
(0.0302)\end{array}$ & $\begin{array}{l}-0.0220^{*} \\
(0.0120)\end{array}$ & $\begin{array}{r}0.2090^{\star * *} \\
(0.0276)\end{array}$ & $\begin{array}{l}-0.0175 \\
(0.0106)\end{array}$ \\
\hline$\%$ Outbound traffic & $\begin{array}{r}-0.0027^{* \star *} \\
(0.0006)\end{array}$ & $\begin{array}{r}0.0011^{* * *} \\
(0.0002)\end{array}$ & $\begin{array}{r}-0.0024^{* * *} \\
(0.0004)\end{array}$ & $\begin{array}{r}0.0009^{* * *} \\
(0.0002)\end{array}$ \\
\hline$\%$ International traffic (Extra EU) & $\begin{array}{r}0.0000 \\
(0.0005)\end{array}$ & $\begin{array}{r}0.0003 \\
(0.0002)\end{array}$ & & \\
\hline Maritime degree [LOG] & $\begin{array}{l}0.0852^{\star *} \\
(0.0372)\end{array}$ & $\begin{array}{r}-0.0825^{\star \star *} \\
(0.0174)\end{array}$ & $\begin{array}{r}0.0673^{* * *} \\
(0.0164)\end{array}$ & $\begin{array}{r}-0.0572^{\star * *} \\
(0.0079)\end{array}$ \\
\hline Hub centrality & $\begin{array}{r}-0.0339 \\
(0.0828)\end{array}$ & $\begin{array}{r}0.0650 \\
(0.0407)\end{array}$ & & \\
\hline \multicolumn{5}{|l|}{ Geographical variables } \\
\hline Latitude (vs. Strasbourg) & $\begin{array}{r}0.0023 \\
(0.0026)\end{array}$ & $\begin{array}{r}-0.0013 \\
(0.0011)\end{array}$ & & \\
\hline Longitude (vs. Strasbourg) & $\begin{array}{r}-0.0018 \\
(0.0016)\end{array}$ & $\begin{array}{l}0.0013^{* *} \\
(0.0006)\end{array}$ & & $\begin{array}{r}0.0007 \\
(0.0005)\end{array}$ \\
\hline Distance nearest larger city & $\begin{array}{r}0.0834^{* * *} \\
(0.0259)\end{array}$ & $\begin{array}{r}-0.0289^{* * *} \\
(0.0100)\end{array}$ & $\begin{array}{r}0.0982^{* * *} \\
(0.0231)\end{array}$ & $\begin{array}{r}-0.0355^{\star \star *} \\
(0.0089)\end{array}$ \\
\hline Population density [LOG] & $\begin{array}{r}-0.0106 \\
(0.0354)\end{array}$ & $\begin{array}{r}0.0180 \\
(0.0142)\end{array}$ & & \\
\hline Population urban area [LOG] & $\begin{array}{l}0.0160^{*} \\
(0.0090)\end{array}$ & $\begin{array}{r}-0.0152^{* * *} \\
(0.0041)\end{array}$ & $\begin{array}{l}0.0168^{* *} \\
(0.0075)\end{array}$ & $\begin{array}{r}-0.0137^{* * *} \\
(0.0037)\end{array}$ \\
\hline Island & $\begin{array}{r}0.0348 \\
(0.0392) \\
\end{array}$ & $\begin{array}{l}-0.0157 \\
(0.0163) \\
\end{array}$ & & \\
\hline \multicolumn{5}{|l|}{ Regional economic variables } \\
\hline$\%$ Industrial sector & $\begin{array}{r}-0.4734 \\
(0.6466)\end{array}$ & $\begin{array}{r}-0.0177 \\
(0.1707)\end{array}$ & & \\
\hline$\%$ Construction sector & $\begin{array}{l}-1.3857^{*} \\
(0.8307)\end{array}$ & $\begin{array}{r}0.5504^{*} \\
(0.3158)\end{array}$ & $\begin{array}{r}-0.8191 \\
(0.5192)\end{array}$ & $\begin{array}{l}0.5068^{\star *} \\
(0.2409)\end{array}$ \\
\hline 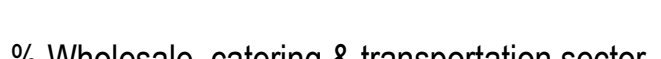 & -0.7800 & 0.0870 & & \\
\hline$\%$ Wholesale, catering \& transportation sector & $(0.5717)$ & $(0.1935)$ & & \\
\hline$\%$ Financial and real estate sector & $\begin{array}{r}0.1401 \\
(0.6807)\end{array}$ & $\begin{array}{r}-0.2539 \\
(0.2140)\end{array}$ & & \\
\hline \% Public administration sector & $-1.1125^{*}$ & $0.3284^{*}$ & $-0.5961^{* * *}$ & $0.1705^{*}$ \\
\hline \% rublic auministration secior & $(0.5780)$ & $(0.1736)$ & $(0.2212)$ & $(0.0868)$ \\
\hline GDP per capita [LOG] & $\begin{array}{r}-0.1005 \\
(0.0889)\end{array}$ & $\begin{array}{l}0.0601^{*} \\
(0.0307)\end{array}$ & & $\begin{array}{r}0.0130 \\
(0.0256)\end{array}$ \\
\hline Regional employment diversity & $\begin{array}{r}-0.0066 \\
(0.0057)\end{array}$ & $\begin{array}{r}-0.0013 \\
(0.0022)\end{array}$ & & \\
\hline & 0.4771 & $0.6179^{* * *}$ & $-0.5217^{* * *}$ & $0.8835^{\star * *}$ \\
\hline Constant & $(0.5596)$ & $(0.1875)$ & $(0.1805)$ & $(0.1380)$ \\
\hline $\mathrm{N}$ & 318 & 318 & 325 & 325 \\
\hline $\mathrm{R}^{2}$ & 0.5429 & 0.5645 & 0.5251 & 0.5356 \\
\hline Root-MSE & 0.1880 & 0.0726 & 0.1867 & 0.0734 \\
\hline
\end{tabular}

N.B. Significant at $* 0.10, * * 0.05, * * * 0.01$ levels 
Table 7: Correlations among main variables

\begin{tabular}{|c|c|c|c|c|c|}
\hline Variable & Commodity 1 & Commodity 2 & Commodity 3 & Commodity 4 & Commodity 5 \\
\hline CDI & $\begin{array}{l}\text { Refined oil } \\
\text { products } \\
(0.65)\end{array}$ & $\begin{array}{c}\text { Containers } \\
(0.62)\end{array}$ & $\begin{array}{c}\text { Crude oil } \\
(0.58)\end{array}$ & $\begin{array}{l}\text { Agricultural } \\
(0.56)\end{array}$ & $\begin{array}{l}\text { Other liquid bulk } \\
\qquad(0.52)\end{array}$ \\
\hline AVG CDI CHANGE & $\begin{array}{l}\text { Liquefied gas } \\
\quad(-0.16)\end{array}$ & $\begin{array}{c}\text { Non-self propelled } \\
\text { vehicles } \\
(-0.14) \\
\end{array}$ & $\begin{array}{c}\text { Self-propelled } \\
\text { vehicles } \\
(-0.12) \\
\end{array}$ & $\begin{array}{l}\text { Rail wagons } \\
\quad(-0.10)\end{array}$ & $\begin{array}{c}\text { Crude oil } \\
(-0.08)\end{array}$ \\
\hline GINI & $\begin{array}{c}\text { Containers } \\
(-0.67)\end{array}$ & $\begin{array}{c}\text { Agricultural } \\
(-0.67)\end{array}$ & $\begin{array}{c}\text { Iron and steel } \\
(-0.63)\end{array}$ & $\begin{array}{l}\text { Other liquid bulk } \\
(-0.60)\end{array}$ & $\begin{array}{c}\text { Other dry bulk } \\
(-0.56)\end{array}$ \\
\hline CAGR 05-06 & $\begin{array}{c}\text { Crude oil } \\
(-0.14)\end{array}$ & $\begin{array}{l}\text { Coal } \\
(0.09)\end{array}$ & $\begin{array}{l}\text { Liquefied gas, } \\
\text { refined oil } \\
(-0.07)\end{array}$ & $\begin{array}{l}\text { Forestry } \\
(-0.05)\end{array}$ & $\begin{array}{l}\text { Other dry bulk } \\
(0.04)\end{array}$ \\
\hline Total traffic & $\begin{array}{c}\text { Crude oil } \\
(0.62)\end{array}$ & $\begin{array}{c}\text { Containers } \\
(0.60)\end{array}$ & $\begin{array}{c}\text { Refined oil } \\
(0.58)\end{array}$ & $\begin{array}{c}\text { Liquefied gas } \\
(0.56)\end{array}$ & $\begin{array}{c}\text { Coal } \\
(0.48) \\
\end{array}$ \\
\hline$\%$ outbound traffic & $\begin{array}{c}\text { Refined oil } \\
(-0.26)\end{array}$ & $\begin{array}{c}\text { Coal, agricultural } \\
(-0.25)\end{array}$ & $\begin{array}{c}\text { Iron and steel } \\
(-0.20)\end{array}$ & $\begin{array}{c}\text { Other liquid bulk } \\
(-0.13)\end{array}$ & $\begin{array}{c}\text { Crude oil } \\
(-0.12)\end{array}$ \\
\hline $\begin{array}{l}\% \text { international } \\
\text { traffic }\end{array}$ & $\begin{array}{c}\text { Forestry products } \\
(0.31)\end{array}$ & $\begin{array}{c}\text { Coal, containers, } \\
\text { ores } \\
(0.19) \\
\end{array}$ & $\begin{array}{l}\text { Agricultural } \\
(0.18)\end{array}$ & $\begin{array}{c}\text { Iron and steel, crude } \\
\text { oil } \\
(0.16) \\
\end{array}$ & $\begin{array}{l}\text { Other dry bulk } \\
(0.15)\end{array}$ \\
\hline Maritime degree & $\begin{array}{c}\text { Containers } \\
(0.80)\end{array}$ & $\begin{array}{c}\text { Other general } \\
\text { cargo } \\
(0.54)\end{array}$ & $\begin{array}{l}\text { Iron and steel, } \\
\text { agricultural } \\
(0.47)\end{array}$ & $\begin{array}{l}\text { Other liquid bulk, } \\
\text { other dry bulk } \\
(0.44)\end{array}$ & $\begin{array}{l}\text { Refined oil, non- } \\
\text { self propelled } \\
\text { vehicles } \\
(0.33)\end{array}$ \\
\hline Hub centrality & $\begin{array}{c}\text { Containers } \\
(0.70)\end{array}$ & $\begin{array}{c}\text { Other general } \\
\text { cargo } \\
(0.49) \\
\end{array}$ & $\begin{array}{l}\text { Other dry bulk } \\
(0.41)\end{array}$ & $\begin{array}{c}\text { Iron and steel, } \\
\text { agricultural } \\
(0.39)\end{array}$ & $\begin{array}{l}\text { Other liquid bulk } \\
\qquad(0.37)\end{array}$ \\
\hline Latitude & $\begin{array}{l}\text { Forestry } \\
(0.24)\end{array}$ & $\begin{array}{l}\text { Liquefied gas } \\
\quad(-0.18)\end{array}$ & $\begin{array}{c}\text { Crude oil, ores, } \\
\text { agricultural } \\
(-0.13) \\
\end{array}$ & $\begin{array}{l}\text { Refined oil } \\
(-0.10)\end{array}$ & $\begin{array}{l}\text { Rail wagons } \\
\quad(0.09)\end{array}$ \\
\hline Longitude & $\begin{array}{l}\text { Agricultural } \\
(-0.20)\end{array}$ & $\begin{array}{l}\text { Liquefied gas } \\
\quad(-0.18)\end{array}$ & $\begin{array}{l}\text { Other dry bulk, } \\
\text { containers } \\
(-0.16)\end{array}$ & $\begin{array}{c}\text { Other general cargo, } \\
\text { iron and steel } \\
(-0.13)\end{array}$ & $\begin{array}{c}\text { Non self-propelled } \\
\text { vehicles, crude oil } \\
(-0.11)\end{array}$ \\
\hline $\begin{array}{l}\text { Distance nearest } \\
\text { larger city }\end{array}$ & $\begin{array}{c}\text { Containers } \\
(0.42)\end{array}$ & $\begin{array}{c}\text { Agricultural } \\
(0.33)\end{array}$ & $\begin{array}{l}\text { Refined oil } \\
(0.29)\end{array}$ & $\begin{array}{c}\text { Other general cargo, } \\
\text { other dry bulk } \\
(0.27)\end{array}$ & $\begin{array}{l}\text { Non self-propelled } \\
\text { vehicles } \\
(0.24)\end{array}$ \\
\hline Urban population & $\begin{array}{c}\text { Containers } \\
(0.59)\end{array}$ & $\begin{array}{l}\text { Agricultural } \\
(0.58)\end{array}$ & $\begin{array}{c}\text { Other general } \\
\text { cargo } \\
(0.50) \\
\end{array}$ & $\begin{array}{l}\text { Other dry bulk } \\
\quad(0.47)\end{array}$ & $\begin{array}{c}\text { Iron and steel } \\
(0.43)\end{array}$ \\
\hline Island dummy & $\begin{array}{l}\text { Forestry } \\
(-0.24)\end{array}$ & $\begin{array}{c}\text { Iron and steel } \\
(-0.18)\end{array}$ & $\begin{array}{l}\text { Agricultural, other } \\
\text { general cargo } \\
(-0.17)\end{array}$ & $\begin{array}{l}\text { Other dry bulk } \\
\quad(-0.15)\end{array}$ & $\begin{array}{c}\text { Containers, coal } \\
(-0.13)\end{array}$ \\
\hline
\end{tabular}

Source: realised by authors based on Eurostat and various sources 
Figure 1: Distribution of European port traffic, 2006

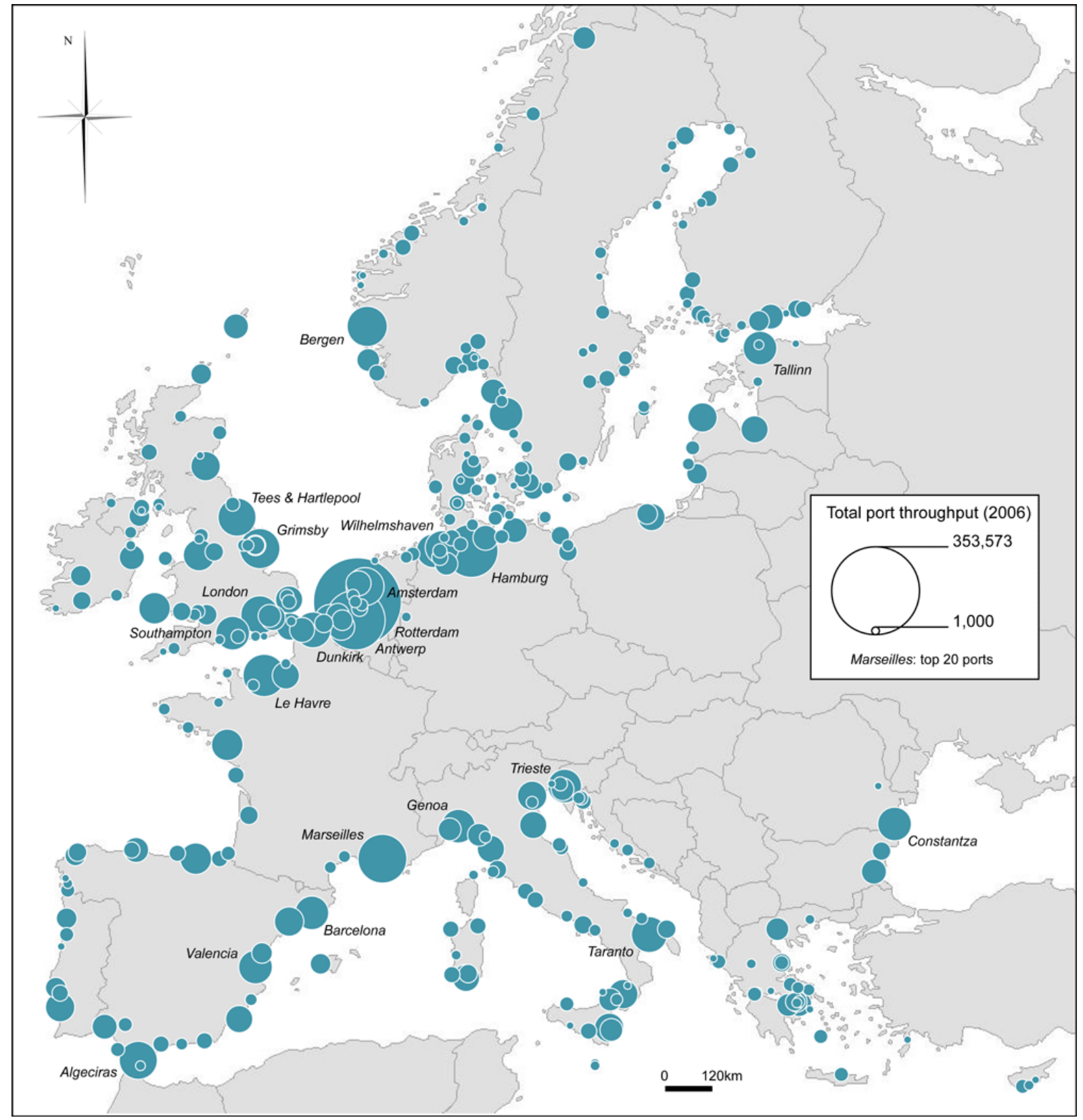

Source: realised by authors based on Eurostat 
Figure 2: Commodity diversity and specialisation at European ports, 2006

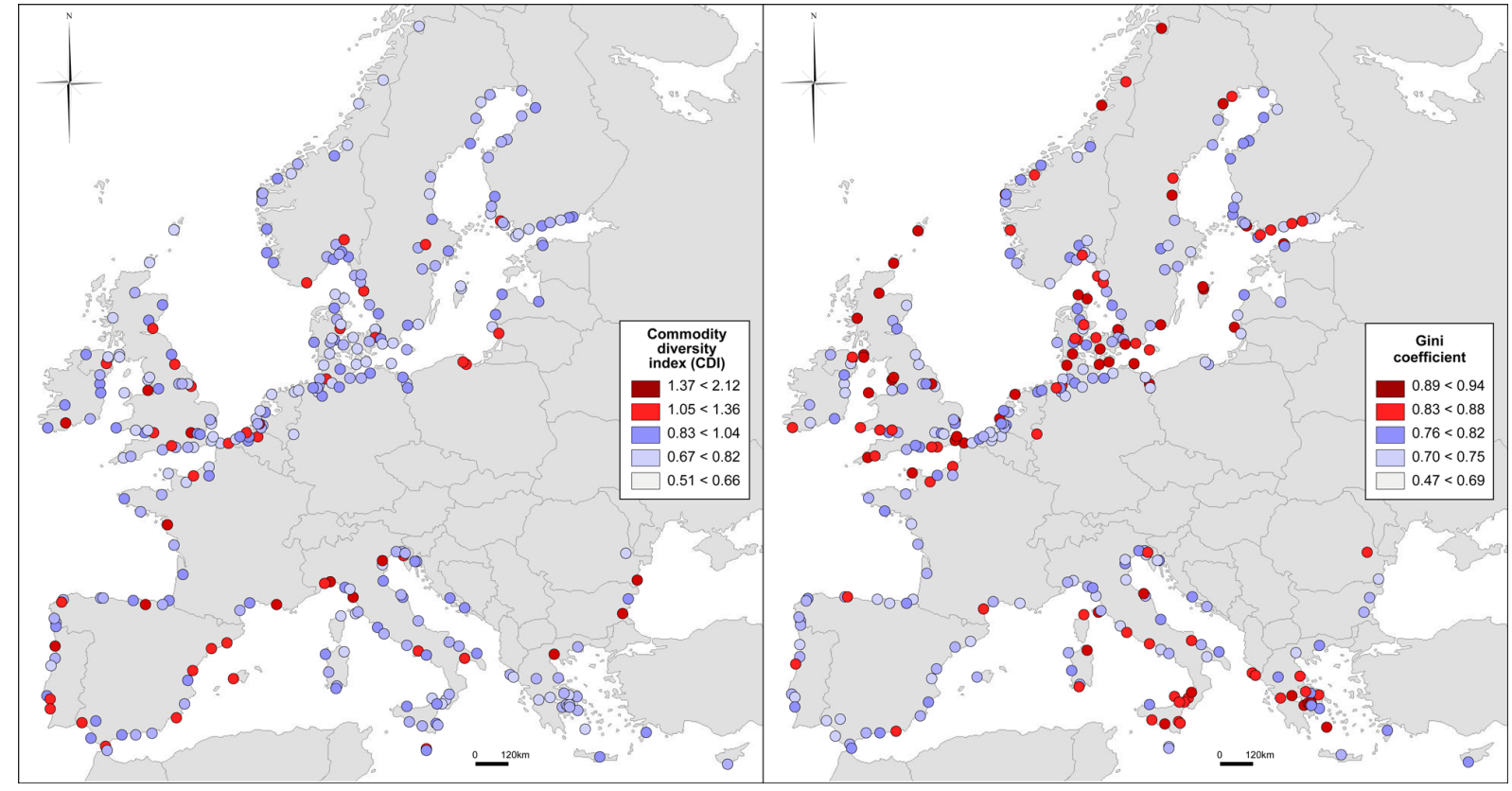

Source: realised by authors based on Eurostat 
Figure 3: Diversity and performance of European ports, 2006

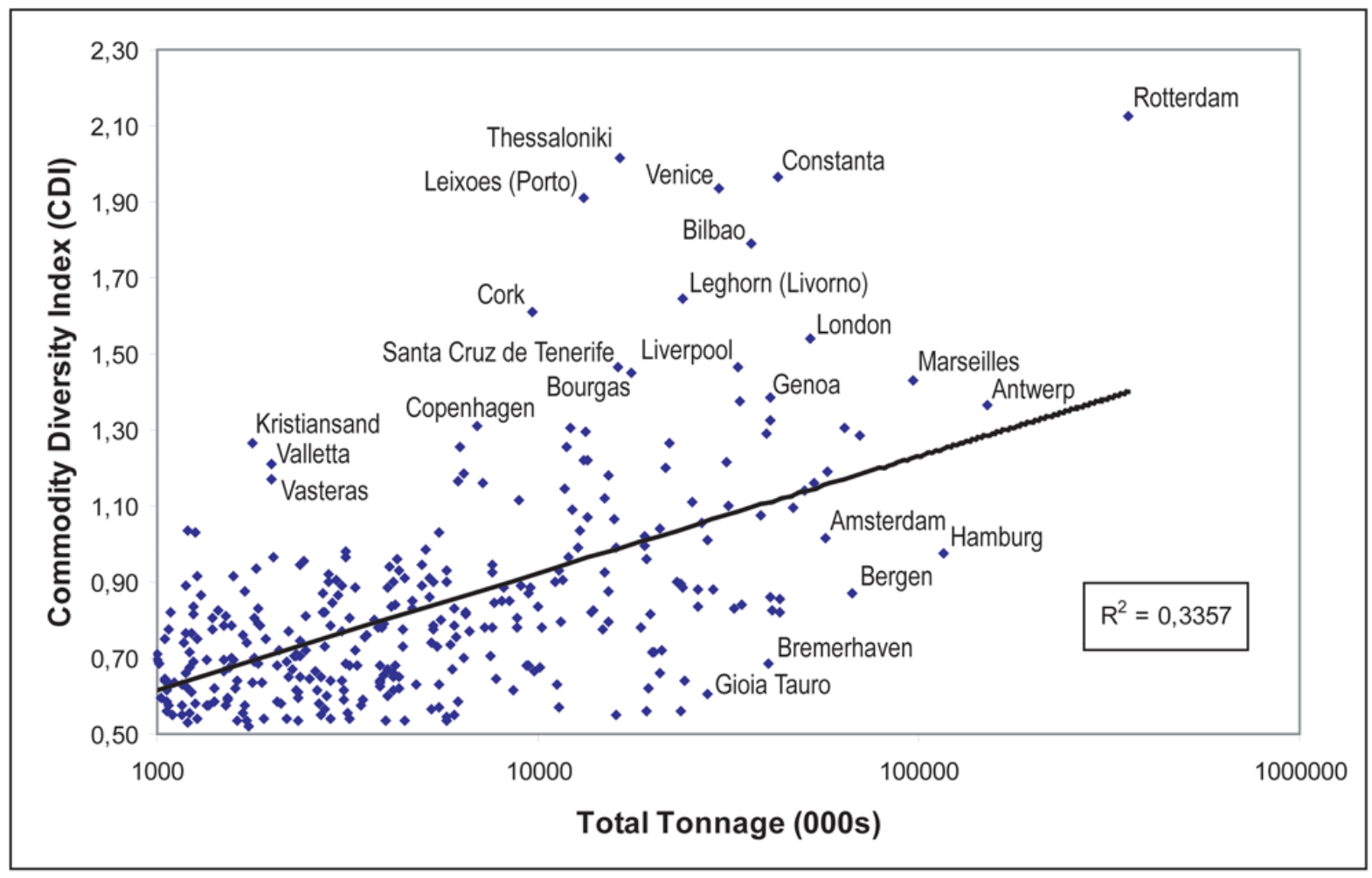

Source: realised by authors based on Eurostat 


\section{Appendix 1: Summary of main variables}

\begin{tabular}{|c|c|c|c|}
\hline $\begin{array}{l}\text { Type of } \\
\text { indicator }\end{array}$ & Indicator & Description & Remark(s) \\
\hline \multirow{6}{*}{$\begin{array}{l}\text { Port } \\
\text { performance }\end{array}$} & Traffic growth & CAGR 2005-2006 & $\begin{array}{l}\text { Short time period allows keeping a } \\
\text { maximum of ports in the sample }\end{array}$ \\
\hline & Total traffic & Thousand metric tons (2006) & Logarithm \\
\hline & Traffic balance & $\begin{array}{l}\text { Share (\%) of outbound traffic in total traffic } \\
(2006)\end{array}$ & $\begin{array}{l}\text { Imbalances in traffic flows relate with } \\
\text { hinterland effect }\end{array}$ \\
\hline & Internationalisation & $\begin{array}{l}\text { Share }(\%) \text { of international traffic (extra- } \\
\text { EU27) in total traffic (2006) }\end{array}$ & Used as a proxy of foreland extension \\
\hline & Maritime degree & $\begin{array}{l}\text { Number of ports directly connected through } \\
\text { liner vessel movements (2006) }\end{array}$ & Logarithm \\
\hline & Hub centrality & $\begin{array}{l}\text { Inverse of the share of the biggest traffic } \\
\text { connection in total traffic (2006) }\end{array}$ & $\begin{array}{l}\text { Relative index of strength in the maritime } \\
\text { system }\end{array}$ \\
\hline \multirow{6}{*}{ Location } & Latitude & $\begin{array}{l}\text { North-South coordinates of the port (based } \\
\text { on Strasbourg) }\end{array}$ & \multirow{2}{*}{$\begin{array}{l}\text { Neutral indicator of position in the core- } \\
\text { periphery pattern regardless of physical } \\
\text { obstacles }\end{array}$} \\
\hline & Longitude & $\begin{array}{l}\text { East-West coordinates of the port (based } \\
\text { on Strasbourg) }\end{array}$ & \\
\hline & Urban centrality & $\begin{array}{l}\text { Road kilometric distance to the nearest } \\
\text { larger city }\end{array}$ & $\begin{array}{l}\text { Includes ferry transfers if applicable; does } \\
\text { not take into account national factors (e.g. } \\
\text { infrastructure quality, boundaries) }\end{array}$ \\
\hline & Urban population & $\begin{array}{l}\text { Number of inhabitants of the morphological } \\
\text { urban agglomeration }\end{array}$ & Logarithm \\
\hline & Population density & $\begin{array}{l}\text { Number of inhabitants of the region per } \\
\text { square kilometre }\end{array}$ & Logarithm; NUTS 2 level \\
\hline & Island & Location or not on an island & $\begin{array}{l}\text { Dummy (0 or 1); UK and Ireland are not } \\
\text { considered islands }\end{array}$ \\
\hline \multirow{3}{*}{$\begin{array}{l}\text { Regional } \\
\text { economy }\end{array}$} & Labour market & $\begin{array}{l}\text { Share of employment by economic sector } \\
\text { in total regional employment }\end{array}$ & $\begin{array}{l}\text { NUTS } 2 \text { level; excludes agriculture because } \\
\text { of multicollinearity }\end{array}$ \\
\hline & $\begin{array}{l}\text { Regional } \\
\text { employment } \\
\text { diversity }\end{array}$ & $\begin{array}{l}\text { Relative diversity index applied to the } \\
\text { distribution of employment shares based } \\
\text { on European average }\end{array}$ & NUTS2 level \\
\hline & $\begin{array}{l}\text { Gross regional } \\
\text { product per capita }\end{array}$ & $\begin{array}{l}\text { Size of the regional economy measured by } \\
\text { the value of all final goods and services } \\
\text { produced in the region }\end{array}$ & NUTS 2 level, logarithm \\
\hline
\end{tabular}

Source: realised by authors based on Eurostat and various sources 


\section{Appendix 2: Top ten ports by selected indicators}

\begin{tabular}{|c|c|c|c|c|c|c|c|c|}
\hline \multirow{2}{*}{$\begin{array}{c}\text { Rank } \\
1\end{array}$} & \multicolumn{2}{|c|}{$\begin{array}{l}\text { Road distance to } \\
\text { nearest bigger city } \\
(\mathrm{km})\end{array}$} & \multicolumn{2}{|c|}{$\begin{array}{l}\text { Urban population } \\
\text { (000s inhab.) }\end{array}$} & \multicolumn{2}{|c|}{$\begin{array}{l}\text { Total tonnage (000s } \\
\text { tons) }\end{array}$} & \multicolumn{2}{|c|}{$\begin{array}{l}\text { Maritime degree (No. } \\
\text { liner connections) }\end{array}$} \\
\hline & Trondheim & 665 & London & 12,600 & Rotterdam & 353,576 & Hamburg & 378 \\
\hline 2 & Stockholm & 659 & Barcelona & 4,971 & Antwerp & 151,704 & Rotterdam & 301 \\
\hline 3 & Umea & 639 & Liverpool & 4,630 & Hamburg & 115,529 & Algeciras & 215 \\
\hline 4 & Barcelona & 630 & Piraeus & 3,853 & Marseille & 96,512 & Marsaxlokk & 205 \\
\hline 5 & Lisboa & 629 & Napoli & 3,840 & Le Havre & 69,974 & Antwerp & 204 \\
\hline 6 & Vigo & 595 & Hamburg & 3,264 & Bergen & 66,670 & Bremerhaven & 193 \\
\hline 7 & Sevilla & 535 & Lisboa & 2,600 & Grimsby-Im, & 64,033 & Le Havre & 173 \\
\hline 8 & Oslo & 526 & Valencia & 1,715 & Algeciras & 57,758 & Valencia & 169 \\
\hline 9 & Thessaloniki & 502 & Stockholm & 1,700 & Amsterdam & 56,794 & Gioia Tauro & 165 \\
\hline 10 & Bergen & 499 & Clydeport & 1,640 & Tees-Hart, & 53,326 & Barcelona & 157 \\
\hline Rank & \multicolumn{2}{|l|}{ CDI } & \multicolumn{2}{|c|}{ GINI (ascending) } & \multicolumn{2}{|c|}{ CDI avg. change 00-06 } & \multicolumn{2}{|c|}{ CAGR 05-06 } \\
\hline 1 & Rotterdam & 2.13 & Gdynia & 0.48 & Constanta & 0.28 & Stigsn. Havn & 1.10 \\
\hline 2 & Thessaloniki & 2.02 & Constanta & 0.49 & Gdansk & 0.14 & Vene Balti & 0.74 \\
\hline 3 & Constanta & 1.96 & Antwerp & 0.51 & Gdynia & 0.09 & Ensted. Havn & 0.64 \\
\hline 4 & Venezia & 1.94 & Hull & 0.52 & Valletta & 0.08 & Dieppe & 0.61 \\
\hline 5 & Leixões & 1.91 & London & 0.52 & Venezia & 0.06 & Asnaes. Havn & 0.58 \\
\hline 6 & Bilbao & 1.79 & Livorno & 0.54 & Ploce & 0.06 & Almyros Volou & 0.53 \\
\hline 7 & Livorno & 1.64 & Venezia & 0.56 & Marsaxlokk & 0.04 & Londonderry & 0.47 \\
\hline 8 & Cork & 1.61 & Rostock & 0.56 & Thessaloniki & 0.04 & Midia & 0.39 \\
\hline 9 & London & 1.54 & Aarhus & 0.58 & Burgas & 0.04 & Marsaxlokk & 0.37 \\
\hline 10 & Liverpool & 1.47 & Szczecin & 0.58 & Vasteras & 0.03 & Pori & 0.35 \\
\hline
\end{tabular}

Source: realised by authors based on Eurostat and various sources

Corresponding author
$2 \quad$ Roll-on roll-off: type of ships requiring ramps for vehicles.

3 For instance, the first and main marketing argument presented in the most recent brochure of the Port of Rotterdam is that 'literally everything passes through the port of Rotterdam. From apples to cars, and from computers to the raw materials for the chemical industry' (source: www.portofrotterdam.com).

$4 \quad$ See the European-wide studies by BRUNET (1989) and ROZENBLAT and CICILLE (2003).

5 This issue is partly solved in Japan (Japan External Trade Organization, JETRO) and the United States

(US Army Corps of Engineers) where detailed traffic data is provided by port, product, weight, and value.

6 see website at: $\underline{\text { http://ec.europa.eu/eurostat/ }}$

7 Maersk (AP Moller-Maersk) is the world's chief container line and a major port operator. 
8 While the port of London serves mostly the local market, the urban agglomeration of Greater London is served by several container ports and terminals located in the South-East, such as Felixstowe, Thamesport, Tilbury, Sheerness, and Southampton.

We calculated the compound annual traffic growth of port $i$ as follows: $G_{i}=\left(\frac{V\left(t_{n}\right)}{V\left(t_{0}\right)}\right)^{\frac{1}{t_{n}-t_{0}}}-1$ where

$V\left(t_{n}\right)$ is the total throughput of port $i$ in 2006 and $V\left(t_{0}\right)$ is the total throughput in 2000 in port $i$.

10 Levene's test statistic is 5.247 which means that the test is significant. Therefore we can conclude that there is no equality of variances between the groups.

11 See the remarkable study of traffic evolution in Antwerp and Rotterdam (1870-2000) by LOYEN et al. (2003). 